\title{
Noise-Induced Loss of Hair Cells and Cochlear Synaptopathy Are Mediated by the Activation of AMPK
}

\author{
Kayla Hill, Hu Yuan, Xianren Wang, and $\$ Su-Hua Sha \\ Department of Pathology and Laboratory Medicine, Medical University of South Carolina, Charleston, South Carolina 29425
}

\begin{abstract}
Noise-induced hearing loss (NIHL) is a major unresolved public health problem. Here, we investigate pathomechanisms of sensory hair cell death and suggest a novel target for protective intervention. Cellular survival depends upon maintenance of energy homeostasis, largely by AMP-activated protein kinase (AMPK). In response to a noise exposure in CBA/J mice, the levels of phosphorylated AMPK $\alpha$ increased in hair cells in a noise intensity-dependent manner. Inhibition of AMPK via siRNA or the pharmacological inhibitor compound $\mathrm{C}$ attenuated noise-induced loss of outer hair cells $(\mathrm{OHCs})$ and synaptic ribbons, and preserved auditory function. Additionally, noise exposure increased the activity of the upstream AMPK kinase liver kinase B1 (LKB1) in cochlear tissues. The inhibition of LKB1 by siRNA attenuated the noise-increased phosphorylation of AMPK $\alpha$ in OHCs, reduced the loss of inner hair cell synaptic ribbons and OHCs, and protected against NIHL. These results indicate that noise exposure induces hair cell death and synaptopathy by activating AMPK via LKB1-mediated pathways. Targeting these pathways may provide a novel route to prevent NIHL.
\end{abstract}

Key words: activation of AMPK; cochlear synaptopathy; noise-induced hearing loss; protection of noise-induced hearing loss; sensory hair cells

\section{Significance Statement}

Our results demonstrate for the first time that the activation of AMP-activated protein kinase (AMPK) $\alpha$ in sensory hair cells is noise intensity dependent and contributes to noise-induced hearing loss by mediating the loss of inner hair cell synaptic ribbons and outer hair cells. Noise induces the phosphorylation of AMPK $\alpha 1$ by liver kinase B1 (LKB1), triggered by changes in intracellular ATP levels. The inhibition of AMPK activation by silencing AMPK or LKB1, or with the pharmacological inhibitor compound C, reduced outer hair cell and synaptic ribbon loss as well as noise-induced hearing loss. This study provides new insights into mechanisms of noise-induced hearing loss and suggests novel interventions for the prevention of the loss of sensory hair cells and cochlear synaptopathy.

\section{Introduction}

Exposure to damaging levels of noise is a major cause of hearing loss worldwide. Animal research has delineated pathomechanisms related to oxidative stress and calcium influx, and potential

Received March 9, 2016; revised May 17, 2016; accepted May 31, 2016.

Author contributions: S.-H.S. designed research; K.H., H.Y., and X.W. performed research; K.H., H.Y., X.W., and S.-H.S. analyzed data; K.H. and S.-H.S. wrote the paper.

This research was supported by Grant R01-DC-009222 from the National Institute on Deafness and Other Communication Disorders, National Institutes of Health. This work was conducted in the WR Building at the Medical University of South Carolina (MUSC) in a renovated space supported by Grant C06-RR-014516. Animals were housed in the MUSC Children' Research Institute animal facilities, which were supported by Grant C06-RR-015455 from the Extramural Research Facilities Program of the National Center for Research Resources. We thank Dr. Jochen Schacht for valuable comments on this manuscript. We also thank the MUSC Biorepository \& Tissue Analysis Shared Resource for technical assistance with cochlear paraffin sections and Andra Talaska for proofreading this manuscript.

The authors declare no competing financial interests.

Correspondence should be addressed to Dr. Su-Hua Sha, Department of Pathology and Laboratory Medicine, Medical University of South Carolina, Walton Research Building, Room 403-E, 39 Sabin Street, Charleston, SC 29425. E-mail: shasu@musc.edu.

DOI:10.1523/JNEUROSCI.0782-16.2016

Copyright $\odot 2016$ the authors $\quad 0270-6474 / 16 / 367497-14 \$ 15.00 / 0$ approaches to pharmacological intervention (Yamane et al., 1995; Yamasoba et al., 1998; Ohlemiller et al., 1999; Ohinata et al., 2000; Le Prell et al., 2007; Fetoni et al., 2013; Yuan et al., 2015). However, there is no clinical treatment to prevent or mitigate the pathology of noise-induced hearing loss (NIHL), which includes loss of sensory hair cells and synaptic connections to the auditory nerve and, consequently, auditory function (Wang et al., 2002; Kujawa and Liberman, 2009; Liberman and Liberman, 2015). Our laboratory has recently reported (Chen et al., 2012) that transient intracellular ATP reduction is one of the initial responses of cochlear tissues to noise exposure in mice, suggesting the involvement of AMP-activated protein kinase (AMPK)related mechanisms in NIHL.

The survival of essentially all organisms depends on the dynamic control of energy metabolism during short-term or longterm exposure to various stressors (Viollet et al., 2010). AMPK is a key cellular energy sensor that is able to detect and react to the increased intracellular levels of AMP that accompany reductions in ATP (Winder and Thomson, 2007). This kinase regulates en- 
ergy homeostasis by directing the cell to switch off energyconsuming pathways and to turn on energy-generating pathways (Hardie et al., 2003; Hardie, 2003; Viollet et al., 2010). The binding of AMP to the AMPK $\gamma$ subunit allosterically activates AMPK twofold to fivefold (Hardie et al., 1999). In addition, the binding of AMP exposes the threonine 172 (T172) residue on the catalytic $\alpha$ subunit to reversible phosphorylation by upstream kinases, such as liver kinase B1 (LKB1). This combined activation via allosteric and phosphorylation mechanisms causes a 1000-fold increase in the kinase activity of AMPK, allowing a high sensitivity in response to small changes in the intracellular energy status (Suter et al., 2006).

Although the activation of AMPK is initially an adaptive response to cellular stress, there are diverse consequences of AMPK activity on cell death and survival. In neuronal cells, AMPK has a neuroprotective effect against glutamate excitotoxicity by elevating glucose transporter 3 trafficking in response to a decrease in cellular ATP levels (Weisová et al., 2011). On the other hand, the prolonged elevation of phosphorylated (p)-AMPK triggers the chronic activation of c-Jun N-terminal protein kinase (JNK), the upregulation of proapoptotic Bim, and the subsequent apoptosis in neuronal and pancreatic cells (Kefas et al., 2004; Yun et al., 2005; Weisová et al., 2011). AMPK is also able to inhibit JNK activity in neuronal cells, suggesting that the regulation of cell fate by AMPK is complex and may depend on the cell type and insult (Schulz et al., 2008; Yun et al., 2009; Weisová et al., 2011).

Despite the central functions of AMPK in the regulation of cell fate, the role of AMPK and its mode of activation in sensory hair cells after inner ear insults have yet to be established. To investigate these questions, we examined the contribution of AMPK and LKB1 to noise-induced hearing loss in CBA/J mice by using siRNA silencing and pharmacological modulators. These studies are the first to explore the role of AMPK and LKB1 in the pathogenesis of noise-induced sensory hair cells loss, cochlear synaptopathy, and subsequent hearing loss.

\section{Materials and Methods}

Animals. Male CBA/J mice at the age of 10 weeks were purchased from The Jackson Laboratory. All mice had free access to water and a regular mouse diet (catalog \#2918; Harlan Sprague Dawley), and were kept at $22 \pm 1{ }^{\circ} \mathrm{C}$ under a standard $12 \mathrm{~h} \mathrm{light/dark}$ cycle to acclimate for at least 1 week before the experiments. Noise exposure was conducted at the age of 12 weeks. All research protocols were approved by the Institutional Animal Care and Use Committee at the Medical University of South Carolina. Animal care was under the supervision of the Division of Laboratory Animal Resources at the Medical University of South Carolina.

Noise exposure. Unrestrained CBA/J male mice at 12 weeks of age were exposed to a broadband noise with a frequency spectrum from 2 to 20 $\mathrm{kHz}$ for $2 \mathrm{~h}$ at either $106 \mathrm{~dB}$ SPL, to induce severe permanent threshold shifts (PTS) that range from 50 to $65 \mathrm{~dB}$ at high frequencies with a loss of both outer hair cells (OHCs) and inner hair cells (IHCs), or $98 \mathrm{~dB}$ SPL, to induce PTS that range from 40 to $50 \mathrm{~dB}$ with the loss of OHCs only examined 2 weeks after the exposure (Yuan et al., 2015). Generally, four mice (one mouse per stainless steel wire cage) were located in the center of the sound chamber, and the levels of sound were consistent throughout the field during the noise exposure. Age- and gender-matched control mice were kept in silence within the same chamber and cages for $2 \mathrm{~h}$ without noise exposure. The sound exposure chamber was the same as previously described (Chen et al., 2012; Zheng et al., 2014; Yuan et al., 2015). Briefly, the chamber was fitted with a loudspeaker (model $2450 \mathrm{H}$; JBL) driven by a power amplifier (model XLS 202D; Crown Audio) fed from a CD player (model Tascam CD-200; TEAC America). Audio CD sound files were created and equalized with audio editing software (Audition 3; Adobe Systems). Sound levels were calibrated with a sound level meter (model 1200; Quest Technologies) at multiple locations within the chamber to ensure the uniformity of the sound field among the four cages, and were measured before and after exposure to ensure stability.

Auditory brainstem responses. Mice were anesthetized with an injection of xylazine $(20 \mathrm{mg} / \mathrm{kg}$, i.p.) and ketamine $(100 \mathrm{mg} / \mathrm{kg}$, i.p.), and then placed in a sound-isolated and electrically shielded booth (Acoustic Systems). Body temperature was maintained near $37^{\circ} \mathrm{C}$ with a heating pad. Acoustic stimuli were delivered monaurally to a Beyer earphone attached to a customized plastic speculum inserted into the ear canal. Subdermal electrodes were inserted at the vertex of the skull, under the left ear and under the right ear (ground). Auditory brainstem responses (ABRs) were measured at 8, 16, and $32 \mathrm{kHz}$. Tucker Davis Technology System III hardware and SigGen/Biosig software were used to present the stimuli (15 ms duration tone bursts with $1 \mathrm{~ms}$ rise-fall time) and record the response. Up to 1200 responses were averaged for each stimulus level. Thresholds were determined for each frequency by reducing the intensity in $10 \mathrm{~dB}$ increments and then in $5 \mathrm{~dB}$ steps near threshold until no organized responses were detected. ABR waves I and II were monitored to assess thresholds. Thresholds were estimated between the lowest stimulus level where a response was observed and the highest level without a response. All ABR measurements were conducted by the same experimenter. The ABR thresholds were assessed by an expert who was blinded to the treatment conditions.

Drug administration via intraperitoneal route. Compound C (CC; catalog \#P5499; Sigma-Aldrich) was dissolved in dimethylsulfoxide (DMSO) as a stock solution $(31.25 \mathrm{mg} / \mathrm{ml})$ and stored at $-20^{\circ} \mathrm{C}$. The stock solution was diluted in $0.9 \%$ saline solution immediately before injection. Each animal received a total of three intraperitoneal injections of compound $\mathrm{C}$ at a dose of 20 or $10 \mathrm{mg} / \mathrm{kg}$ per injection. The three intraperitoneal injections were administered $24 \mathrm{~h}$ before, $2 \mathrm{~h}$ before, and immediately after noise exposure. The animals were decapitated $1 \mathrm{~h}$ after noise exposure, and the temporal bones were removed to dissect the cochlea for immunohistochemistry assays. The mice used for experiments to observe the progression of ABR thresholds received an additional intraperitoneal injection $24 \mathrm{~h}$ after noise exposure.

Intratympanic delivery of siRNA. AMPK $\alpha 1$ siRNA (siAMPK $\alpha 1$; catalog \#s98535; Invitrogen), siLKB1 (catalog \#s74497; Invitrogen), or scrambled siRNA (siControl; Invitrogen) was locally delivered via intratympanic application, which allows the entry of siRNA specifically within sensory hair cells with minimal uptake in other cochlear cell types, as previously described (Chen et al., 2013; Oishi et al., 2013). Briefly, after anesthesia, a retroauricular incision was made to approach the temporal bone. The otic bulla was identified ventral to the facial nerve, and a shallow hole was made in the thin part of the otic bulla with a 30 ga needle and enlarged with a dental drill to a diameter of $2 \mathrm{~mm}$ to visualize the round window. A customized sterile micro medical tube was inserted into the hole just above the round window to slowly deliver $10 \mu \mathrm{l}(0.3$, 0.6 , or $0.9 \mu \mathrm{g}$ ) of a single siRNA type via syringe. Although the volume of the mouse middle ear cavity is 5-8 $\mu \mathrm{l}$, we slowly flushed $10 \mu \mathrm{l}$ of the siRNA solution into the cavity, as some of the solution flows out through the $2 \mathrm{~mm}$ hole made for access to the round window niche. After siRNA delivery, the hole was covered with surrounding muscle and glued with tissue adhesive. Last, the skin incision was closed with tissue adhesive, and the mouse was kept in the surgical position for $1 \mathrm{~h}$. Based on our previous experiments (Oishi et al., 2013; Zheng et al., 2014), local intratympanic delivery of siRNA results in temporary elevation of thresholds that completely recovers by $72 \mathrm{~h}$. Therefore, noise exposure was performed $72 \mathrm{~h}$ after siRNA delivery.

Surface preparations and diaminobenzidine staining of cochlear epithelia for hair cell counts. The procedures for surface preparations and diaminobenzidine (DAB) staining of cochlear epithelia were followed as previously described (Chen et al., 2012). Briefly, the temporal bones were removed immediately following the decapitation of the mice, and were perfused through the cochlear scala media with a solution of $4 \%$ paraformaldehyde in PBS, pH 7.4, and kept in this fixative overnight at $4^{\circ} \mathrm{C}$. The cochleae were then rinsed in PBS. Before decalcification in a $4 \%$ solution of sodium EDTA (adjusted with $\mathrm{HCl}$ to $\mathrm{pH}$ 7.4), the apical otic capsule was removed from each cochlea. The EDTA solution was changed daily for $3 \mathrm{~d}$ and maintained at $4^{\circ} \mathrm{C}$. Following decalcification, the cochleae were placed in $3 \%$ hydrogen peroxide for $2.5 \mathrm{~h}$ to quench 
endogenous peroxidases. After incubation in a solution for blocking nonspecific antibody binding overnight at $4^{\circ} \mathrm{C}$, the tissues were incubated with a primary antibody (rabbit polyclonal anti-myosin VIIa; catalog \#25-6790; Proteus Biosciences) at a 1:100 dilution for $4 \mathrm{~d}$ at $4^{\circ} \mathrm{C}$ on a Nutator mixer, washed in PBS, and then incubated overnight at $4^{\circ} \mathrm{C}$ with secondary antibody (biotinylated goat anti-rabbit) at a 1:100 dilution. The specimens were rinsed again and then incubated in $\mathrm{ABC}$ solution (catalog \#PK-4001; Vector Laboratories) overnight. Following another washing, the cochleae were incubated in DAB for $3 \mathrm{~h}$, as necessary for sufficient staining intensity, followed by washing to stop the DAB reaction. Finally, the cochleae were microdissected under a microscope into equally sized apical, middle, and basal segments, and mounted on slides with Fluoromount-G mounting medium. Images were taken with Zeiss AxioCam MRc5 camera with Axioplan 2 imaging software with a Zeiss microscope for hair cell counts. Hair cells were counted from captured images using the $40 \times$ magnification lens on the Zeiss microscope from the apex through the base of the DAB-stained surface preparations. The lengths of the cochlear epithelia were measured and recorded in millimeters. Both outer and inner hair cells were counted from the apex to the base along the entire length of the mouse cochlear epithelium. The percentages of hair cell loss in each $0.5 \mathrm{~mm}$ length of epithelium were plotted as a function of the cochlear length as a cytocochleogram (Chen et al., 2012).

Immunohistochemistry for cochlear paraffin sections. Following decalcification with $4 \%$ EDTA, each cochlea was transferred to $70 \%$ ethanol and embedded in paraffin for sections. Five-micrometer formalin-fixed paraffin-embedded (FFPE) sections were routinely deparaffinized in xylene and rehydrated in alcohol. The sections were incubated with target retrieval solution (catalog \#S2367; Dako) in a steamer (catalog \#CKSTSTMD5-W; Oster) for $10 \mathrm{~min}$, and then 3\% hydrogen peroxide for 10 min and protein block (catalog \#0909; Dako) for $20 \mathrm{~min}$ at room temperature. A monoclonal primary antibody [p-AMPK $\alpha$ at 1:100 (catalog \#2535; Cell Signaling Technology); AMPK $\alpha 1$ at 1:200 (cata$\log$ \#ab32047; Abcam); AMPK $\alpha 2$ at 1:100 (catalog \#ab3760; Abcam); p-LKB1 (S428) at 1:500 (catalog \#SAB4504034; Sigma-Aldrich)] was incubated overnight in a humid chamber at $4^{\circ} \mathrm{C}$, followed by biotinylated secondary antibody (Vector Laboratories) for $30 \mathrm{~min}$ and $\mathrm{ABC}$ reagent (Vector Laboratories) for $30 \mathrm{~min}$. Immunocomplexes of horseradish peroxidase were visualized by $\mathrm{DAB}$ (Dako) reaction, and sections were counterstained with hematoxylin before mounting.

Immunohistochemistry of cochlear surface preparations. Following decalcification with 4\% EDTA, each cochlea for immunocytochemistry of surface preparations was dissected under a microscope by removing the softened otic capsule, stria vascularis, Reissner's membrane, and tectorial membrane. The remaining tissue, including the modiolus and cochlear sensory epithelium, was permeabilized in 3\% Triton X-100 solution for $30 \mathrm{~min}$ at room temperature. The specimens were washed three times with PBS and blocked with $10 \%$ goat serum for $30 \mathrm{~min}$ at room temperature. For immunolabeling of hair cell proteins, the tissues were incubated at $4^{\circ} \mathrm{C}$ overnight with the following primary antibodies: monoclonal rabbit anti-p-AMPK $\alpha$ (T177) at 1:50 (catalog \#2535S; Cell Signaling Technology); or monoclonal rabbit anti-p-LKB1 at 1:50 (cata$\log$ \#3482; Cell Signaling Technology). After washing three times, the tissues were incubated with the Alexa Fluor 594-conjugated secondary antibody at a concentration of $1: 200$ at $4^{\circ} \mathrm{C}$ overnight in darkness. After washing, specimens were then incubated with Alexa Fluor 488 phalloidin at a $1: 1000$ at room temperature $\left(25^{\circ} \mathrm{C}\right)$ for $20 \mathrm{~min}$ in darkness. For immunolabeling of synaptic ribbons and glutamate receptors, the cochleae were fixed for $45 \mathrm{~min}$. After the decalcification, tissues were incubated at $37^{\circ} \mathrm{C}$ overnight with the following primary antibodies: monoclonal mouse anti-carboxyl-terminal binding protein 2 (CtBP2) IgG1 at 1:200 (\#612044; BD Biosciences) and monoclonal mouse antiGluR2 IgG2a at 1:2000 (catalog MAB397; Millipore). After washing three times, the tissues were incubated with the Alexa Fluor 594- and Alexa Fluor 488-conjugated secondary antibodies at a concentration of 1:1000 at $37^{\circ} \mathrm{C}$ for $1 \mathrm{~h}$ in darkness. After washing three times, the tissues were reincubated with Alexa Fluor-conjugated secondary antibodies for an additional $1 \mathrm{~h}$ at $37^{\circ} \mathrm{C}$ to increase the immunolabeling for GluR2 (Wan et al., 2014). After washing three times, the tissues were incubated in dark- ness at $4^{\circ} \mathrm{C}$ overnight with polyclonal rabbit anti-myosin VIIa at 1:200 (catalog \#25-6790; Proteus Biosciences). Following washing steps, the tissues were incubated with Alexa Fluor 350-conjugated secondary antibody at a concentration of 1:200 at $4^{\circ} \mathrm{C}$ overnight in darkness. For all immunolabeling samples, after the final wash with PBS, the tissue was dissected in PBS by removing the modiolus. The epithelia were divided equally into three segments (apex, middle, and base). Specimens were mounted on slides with Fluoro-gel with Tris buffer (catalog \#17985-10; Electron Microscopy Sciences). Control incubations were routinely processed without primary antibody treatments. Immunolabeled images were taken using a laser confocal microscope (model LSM 510, Zeiss; or TCS SP5 AOBS, Leica).

Quantification of the immunolabeled signals from outer hair cells of surface preparations. Immunolabeled signals of OHCs on surface preparations were quantified from original confocal images, each taken with a $63 \times$ magnification lens under identical conditions and equal parameter settings for laser gains and photomultiplier tube (PMT) gains, using ImageJ software (National Institutes of Health). The cochleae from the different groups were fixed and stained simultaneously with identical solutions and processed in parallel. All of the surface preparations were counterstained with Alexa Fluor 488 phalloidin (green) to label hair cell structure. The borders of each individual $\mathrm{OHC}$ were outlined with the circle tool based on the phalloidin staining. The immunolabeling for the target proteins was measured in the basal region of cochlear surface preparations in $0.12 \mathrm{~mm}$ segments, each containing $\sim 60$ OHCs. The intensity of the background fluorescence was subtracted, and the average fluorescence per cell was calculated. The fluorescence was quantified by normalizing the ratio of average fluorescence of noise-exposed hair cells to the average fluorescence of the unexposed hair cells. In these studies, there were no differences in the levels of p-AMPK $\alpha$ and LKB1 molecules in OHCs of the apical and middle turns between ears of control mice and those harvested $1 \mathrm{~h}$ after noise.

Quantification of the immunolabeled ribbons from z-projections on surface preparations. Immunolabeling of $\mathrm{CtBP} 2$ on surface preparations was quantified from original confocal images, each taken with a $63 \times$ magnification lens under identical $z$-stack conditions with 0.25 intervals and equal parameter settings for laser gains and PMT. The $z$-stack images in each $0.12 \mathrm{~mm}$ segment (containing $\sim 16$ IHCs) were captured from cochlear surface preparations. The number of synaptic ribbons was counted using ImageJ software. Briefly, the background of the images was subtracted and the threshold was set to isolate the immunolabeling of signals from IHCs. The image was converted to a binary file and the number of ribbon particles was counted using the 3D Object Counter. The binary file was converted to a $3 \mathrm{D} z-y$ projection to measure ribbon dispersion. The number of functional synapses, identified by juxtaposed CtBP2 and GluR2, were manually counted by visualizing the presence of GluR2 colocalization with CtBP2.

Extraction of total cochlear protein. Cochleae were rapidly removed and dissected in ice-cold PBS, pH 7.4, containing complete mini EDTA-free protease inhibitor cocktail tablets (catalog \#11836170001; Roche Diagnostics). To extract total protein, tissues from the cochleae of a single mouse were homogenized in ice-cold RIPA lysis buffer containing RIPA lysis buffer (catalog \#R0278; Sigma-Aldrich) plus phosphatase inhibitor cocktails II and III, and Roche protease inhibitor by using a glass/glass microtissue grind pestle and vessel for $30 \mathrm{~s}$. Tissue debris were removed by centrifugation at $10,000 \times g$ at $4^{\circ} \mathrm{C}$ for $10 \mathrm{~min}$, and the supernatants were retained as the total protein fractions. Protein concentrations were determined using the Bio-Rad Protein Assay dye reagent with bovine serum albumin as a protein standard. Two cochleae from the same mouse were pooled for each sample. Unless otherwise specified, all chemicals and reagents used were purchased from Sigma-Aldrich.

Extraction of protein from formalin-fixed sensory epithelia. Cochleae were rapidly removed and perfused with $4 \%$ paraformaldehyde through the cochlear scala media and incubated for $2 \mathrm{~h}$ at room temperature $\left(25^{\circ} \mathrm{C}\right)$. The cochleae were then rinsed in PBS and decalcified in a $4 \%$ solution of sodium EDTA for $3 \mathrm{~d}$ at $4{ }^{\circ} \mathrm{C}$, with the EDTA solution changed daily. Following decalcification, the dissected sensory epithelia from three mice were placed in $1.5 \mathrm{ml}$ collection tubes 

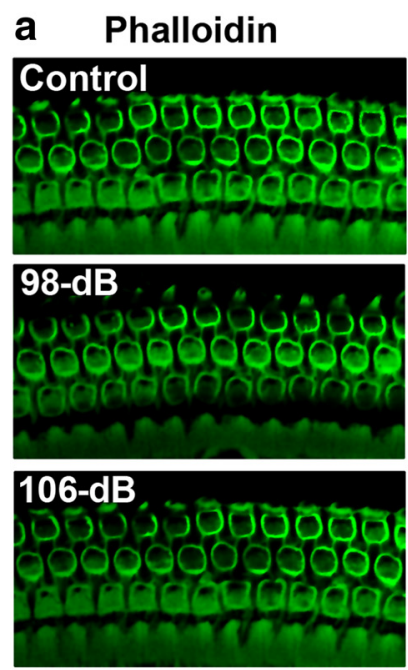

c
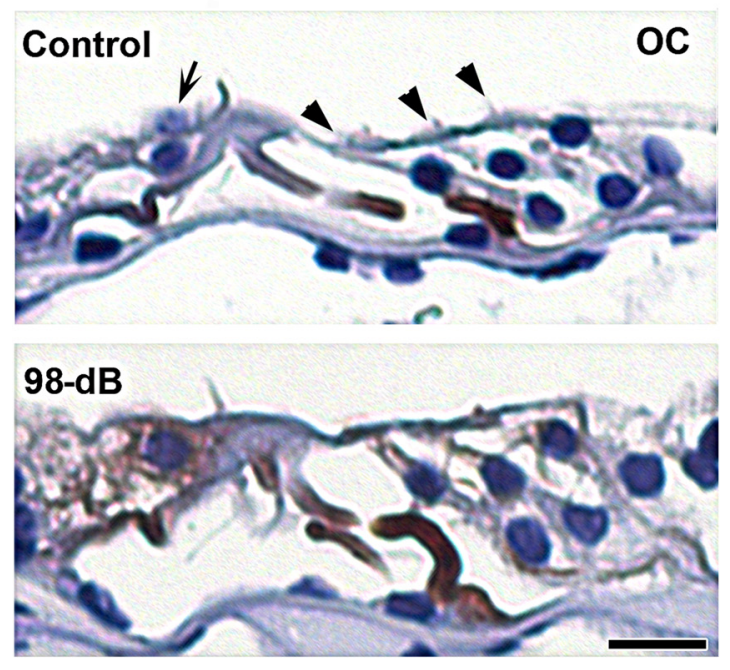

p-AMPK $\alpha(T h r 172)$
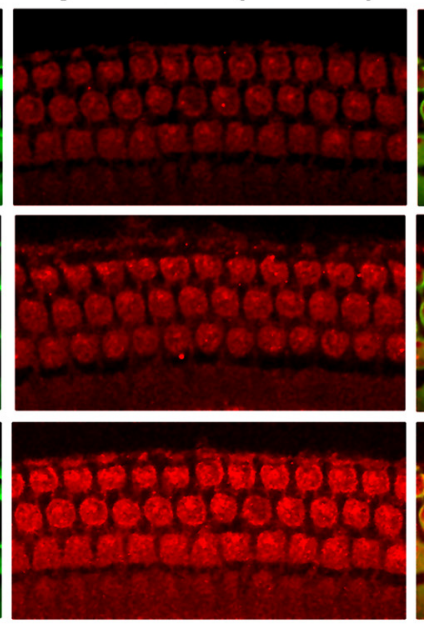

p-AMPK $\alpha$ (Thr172) / Hematoxylin
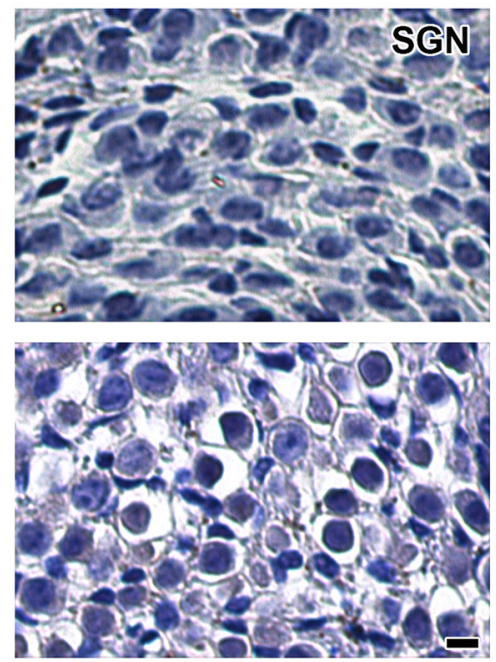

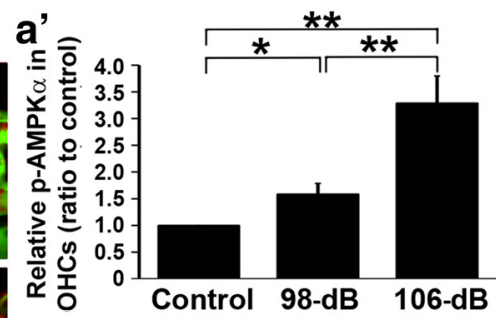

b

p-AMPK $\alpha$

AMPK $\alpha$

GAPDH

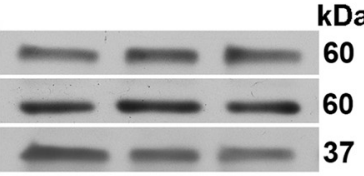

Control 98-dB 106-dB

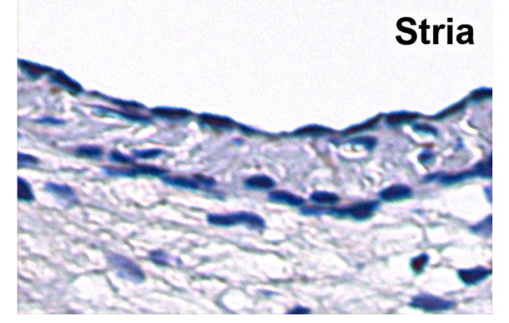

Figure 1. Noise exposure increased p-AMPK $\alpha$ in basal outer and inner hair cells in a noise intensity-dependent manner. $\boldsymbol{a}$, The p-AMPK $\alpha$ immunolabeling (red) was stronger in basal OHCs (green) $1 \mathrm{~h}$ after exposure to 98 or $106 \mathrm{~dB}$ noise than unexposed controls. Representative images were taken from the basal turn. $\boldsymbol{a}^{\prime}$, Quantification of p-AMPK $\alpha$ immunolabeling in basal $0 \mathrm{HCs}$ confirmed significant increases in a noise intensity-dependent fashion. Data are presented as the mean $\pm \mathrm{SD}$. ${ }^{* *} p<0.01,{ }^{*} p<0.05$. Control, $n=4 ; 98 \mathrm{~dB}, n=3 ; 106 \mathrm{~dB}, n=4 . \boldsymbol{b}$, Western blot using sensory epithelium tissues displayed antibody specificity for p-AMPK $\alpha$ and total AMPK $\alpha$, but no alteration in band density for p-AMPK $\alpha$ and total AMPK $\alpha$ examined $1 \mathrm{~h}$ after 98 or $106 \mathrm{~dB}$ exposure compared with unexposed controls. GAPDH served as the loading control; $n=4$.c, Sections of the adult CBA/J mouse cochlea showed increased DAB-stained immunolabeling for $p$-AMPK $\alpha$ (brown) in IHCs (arrow) and OHCs (arrowheads) of the organ of Corti (OC), but no obvious changes in SGN or the stria vascularis (Stria) $1 \mathrm{~h}$ after $98 \mathrm{~dB}$ exposure. There was strong immunolabeling for p-AMPK $\alpha$ in outer and inner pillar cells in both control and noise-exposed mice. Representative images were taken from the upper basal turn. Scale bars: a, c, $10 \mu \mathrm{m}$.

with $100 \mu \mathrm{l}$ of extraction buffer EXB Plus (Qproteome FFPE Tissue Kit \#37623; Qiagen) supplemented with $\beta$-mercaptoethanol. Glass microgrinder pestles were used to grind the tissue for $3 \mathrm{~min}$. The tubes were sealed with a sealing clip and vortexed. The samples were incubated on ice for $5 \mathrm{~min}$, followed by repeat vortexing. The tubes were then incubated for $20 \mathrm{~min}$ at $100^{\circ} \mathrm{C}$ on a heating block. After this incubation, the tubes were incubated for $2 \mathrm{~h}$ at $80^{\circ} \mathrm{C}$ with agitation at $750 \mathrm{rpm}$ (Eppendorf) and then allowed to cool at $4^{\circ} \mathrm{C}$ for $1 \mathrm{~min}$. Finally, the samples were centrifuged at $14,000 \times g$ at $4^{\circ} \mathrm{C}$ for $15 \mathrm{~min}$. The supernatant containing the extracted proteins were transferred to a new tube. Protein concentrations were determined using the BioRad RC DC protein assay (catalog \#500-0119; Invitrogen) with bovine serum albumin as a protein standard.

Western blot analysis. Protein samples $(30 \mu \mathrm{g})$ were separated by SDS-PAGE. After electrophoresis, the proteins were transferred onto a nitrocellulose membrane (Pierce) and blocked with 5\% nonfat dry milk in PBS plus $0.1 \%$ Tween 20 (PBS-T). The membranes were incubated with anti-p-LKB1 (1:1000; catalog \#3482; Cell Signaling Technology), anti-LKB1 (1:1000), or anti-GAPDH (1:10,000; catalog
\#MAB374; Millipore) at $4^{\circ} \mathrm{C}$ overnight, and then washed three times (10 min each) with PBS-T buffer. Membranes were incubated with an appropriate secondary antibody at a concentration of 1:2500 for $1 \mathrm{~h}$. Following extensive washing of the membrane, the immunoreactive bands were visualized by SuperSignal West Dura Extended Duration Substrate or Thermo Scientific Pierce ECL Western Blotting Substrate (ThermoFisher Scientific). The $\mathrm{x}$-ray films of Western blots were scanned and analyzed using ImageJ software. The band densities were first normalized to background. Next, the probing protein/GAPDH ratio was calculated from the band densities run on the same gel. Finally, the difference in the ratio of the control and experimental bands was tested for statistical significance.

Extraction of total cochlear RNA for quantitative PCR. Cochleae were rapidly removed and isolated in RNAlater (Invitrogen). Cochleae from a single mouse were placed in a $2 \mathrm{ml}$ tube with $100 \mu \mathrm{l}$ of RNAlater and immediately crushed with forceps. A $1 \mathrm{ml}$ volume of TRIzol (Invitrogen) was added to each sample, followed by homogenization with an RNase-free Polytron Tissue Grinder (Kinematica). The samples were incubated for $5 \mathrm{~min}$ at room temperature before the 


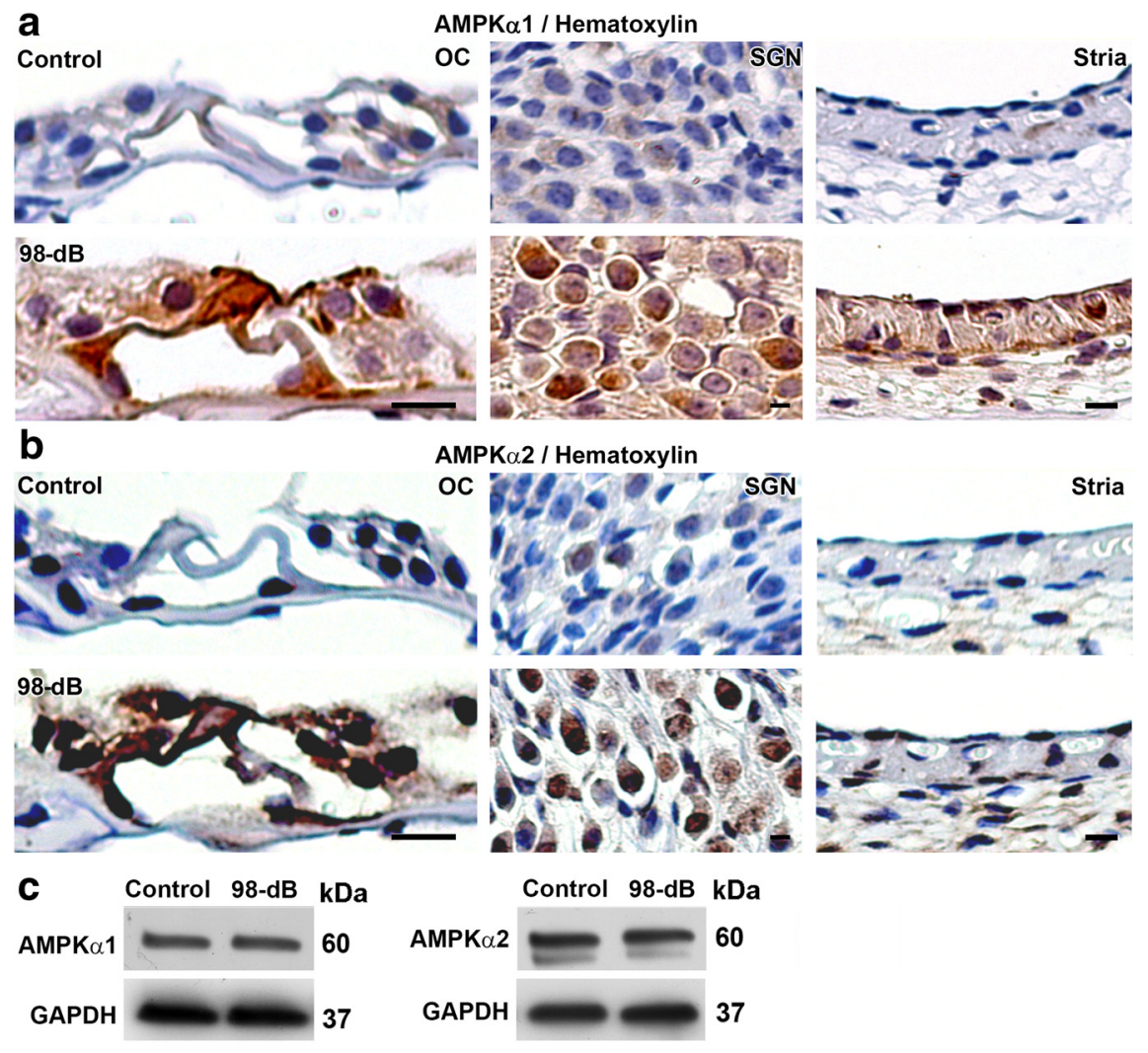

Figure 2. Noise exposure increased total AMPK $\alpha 1$ and AMPK $\alpha 2$ in the organ of Corti. $\boldsymbol{a}, \boldsymbol{b}$, Paraffin sections of the adult CBA/J mouse cochlea revealed localization of DAB-stained immunolabeling for total AMPK $\alpha 1(\boldsymbol{a})$ or AMPK $\alpha 2(\boldsymbol{b}$; brown) in the organ of Corti $(0 C)$, including in $0 \mathrm{HCS}, \mathrm{HCS}$, inner and outer pillar cells, SGNs, and marginal and basal cells of the stria vascularis (Stria) $1 \mathrm{~h}$ after $98 \mathrm{~dB}$ noise exposure. AMPK $\alpha 1$ was mainly localized in the cytosol, while AMPK $\alpha 2$ was predominantly localized in the nuclei. Representative images were taken from the basal turn. Scale bar, $10 \mu \mathrm{m}$. c, Western blots for analysis of total AMPK $\alpha 1$ and AMPK $\alpha 2$ revealed no changes after the noise exposure. GAPDH served as the sample loading control. $n=3$.
SPL) to evaluate the $\mathrm{p}$-AMPK $\alpha$ (Chen et al., 2012; Yuan et al., 2015). Under the 106 $\mathrm{dB}$ noise exposure condition, there was no IHC loss noted at $1 \mathrm{~h}$ after the exposure, but apoptotic and necrotic outer hair cell death appeared in the lower basal region (beginning $\sim 5 \mathrm{~mm}$ from the apex; Chen et al., 2012; Zheng et al., 2014). Immunolabeling for p-AMPK $\alpha$ at threonine 172 in OHCs $1 \mathrm{~h}$ after $92 \mathrm{~dB}$ exposure was similar to age-matched controls without the exposure; however, after $98 \mathrm{~dB}$ exposure, immunolabeling for $\mathrm{p}$-AMPK $\alpha$ in $\mathrm{OHCs}$ at basal turn was increased by $60 \%(p=$ $\left.0.013, t_{(10)}=2.994\right)$ and $230 \%$ after 106 $\mathrm{dB}$ exposure $\left(p=0.003, t_{(3)}=8.971\right)$. Furthermore, the increase in $\mathrm{p}-\mathrm{AMPK} \alpha$ by $106 \mathrm{~dB}$ exposure was significantly higher than after a $98 \mathrm{~dB}$ exposure $\left(p=0.004, t_{(5)}=-5.119\right.$; Fig. $\left.1 a, a^{\prime}\right)$. Since changes in AMPK $\alpha$ phosphorylation were detected only following 98 and $106 \mathrm{~dB}$ exposures leading to PTS, these conditions were used for the rest of the study.

To evaluate the localization of this increased p-AMPK $\alpha$ in three key regions of the cochlea, the organ of Corti, spiral ganglion neurons (SGNs), and stria vascularis, $\mathrm{p}$-AMPK $\alpha$ was immunolabeled in cochlear paraffin sections. In nonexposed control animals, immunolabeling for p-AMPK $\alpha$ was weak in OHCs (arrowheads) and IHCs (arrow), but was stronger in both outer and inner pillar cells. One hour after a $98 \mathrm{~dB}$ noise exposure, the immunolabeling for $\mathrm{p}$-AMPK $\alpha$ was addition of $0.2 \mathrm{ml}$ of chloroform and vigorous shaking. After $2-3 \mathrm{~min}$ of incubation, the samples were centrifuged at $12,000 \times g$ at $4^{\circ} \mathrm{C}$ for 15 $\mathrm{min}$, and the upper colorless aqueous phase was retained and transferred to phase-lock gel heavy tubes (Eppendorf). A total of $0.2 \mathrm{ml}$ of chloroform was added to each sample and followed by centrifugation at $12,000 \times g$ at $4^{\circ} \mathrm{C}$ for $10 \mathrm{~min}$. The upper aqueous phase was transferred to a fresh RNase-free tube for RNA precipitation with $1.5 \mu \mathrm{l}$ of glycogen and $0.5 \mathrm{ml}$ of isopropanol, followed by centrifugation at $12,000 \times g$ at $4^{\circ} \mathrm{C}$ for $10 \mathrm{~min}$. The RNA pellet was washed in $75 \%$ ethanol and dissolved in DEPC water. RNA concentrations were determined using a NanoDrop spectrophotometer. Relative expression levels were analyzed using the Light Cycler 480 (Roche). Unless otherwise specified, all chemicals and reagents used were purchased from Sigma-Aldrich.

Statistical analysis. Data were analyzed using SYSTAT and GraphPad software for Windows. The group size ( $n$ ) in vivo was determined by the variability of measurements and the magnitude of the differences between groups. Statistical methods used include one-way ANOVA with Tukey's multiple comparisons, repeated-measures ANOVA with post hoc testing, unpaired $t$ tests, and one-sample $t$ tests. All tests were two tailed, and a $p$ value of $<0.05$ was considered to be statistically significant.

\section{Results}

AMPK $\alpha$ is phosphorylated in basal OHCs in a noise intensitydependent manner

Based on our previously characterized parameters for CBA/J mice, we used specific noise conditions for temporary threshold shifts without OHC loss (92 dB SPL), PTS with only OHC loss (98 $\mathrm{dB}$ SPL), and severe PTS with both outer and IHC loss (106 dB changed only in IHCs and OHCs with a stronger change in IHCs and marginal elevation in OHCs; no obvious changes were detected in either outer or inner pillar cells, and p-AMPK $\alpha$ immunolabeling remained relatively weak within Deiters cells of the organ of Corti, the SGNs, and the stria vascularis (Fig. 1c). The strong immunolabeling for $\mathrm{p}-\mathrm{AMPK} \alpha$ in outer and inner pillar cells in both control and exposed mice is in agreement with previous observations (Nagashima et al., 2011). Western blots, using formalin-fixed tissues of the sensory epithelia, detected a single band for p-AMPK $\alpha$ at $63 \mathrm{kDa}$, indicating the specificity of the antibody. Changes in band density of $\mathrm{p}-\mathrm{AMPK} \alpha$ with noise exposure were not detectable (Fig. $1 b$ ).

Since noise exposure increased the levels of phosphorylated AMPK $\alpha$ in basal OHCs by immunohistochemistry analysis from confocal images, we also examined the expression of total AMPK $\alpha$ in cochlear cell types by cochlear paraffin sections. In the control animals, immunolabeling for total AMPK $\alpha 1$ was primarily localized to Deiters and pillar cells of the organ of Corti. One hour after a $98 \mathrm{~dB}$ noise exposure, AMPK $\alpha 1$ was increased in the cytosol of OHCs, IHCs, and pillar cells in the organ of Corti, in SGNs, and in the stria vascularis, including marginal and basal cells, and fibrocytes in the spiral ligament (Fig. 2a). Likewise, AMPK $\alpha 2$ immunolabeling was increased in the nuclei and cytosol of IHCs, OHCs, supporting cells, SGNs, and lateral wall structures (Fig. $2 b)$. In contrast, Western blots for the analysis of total 

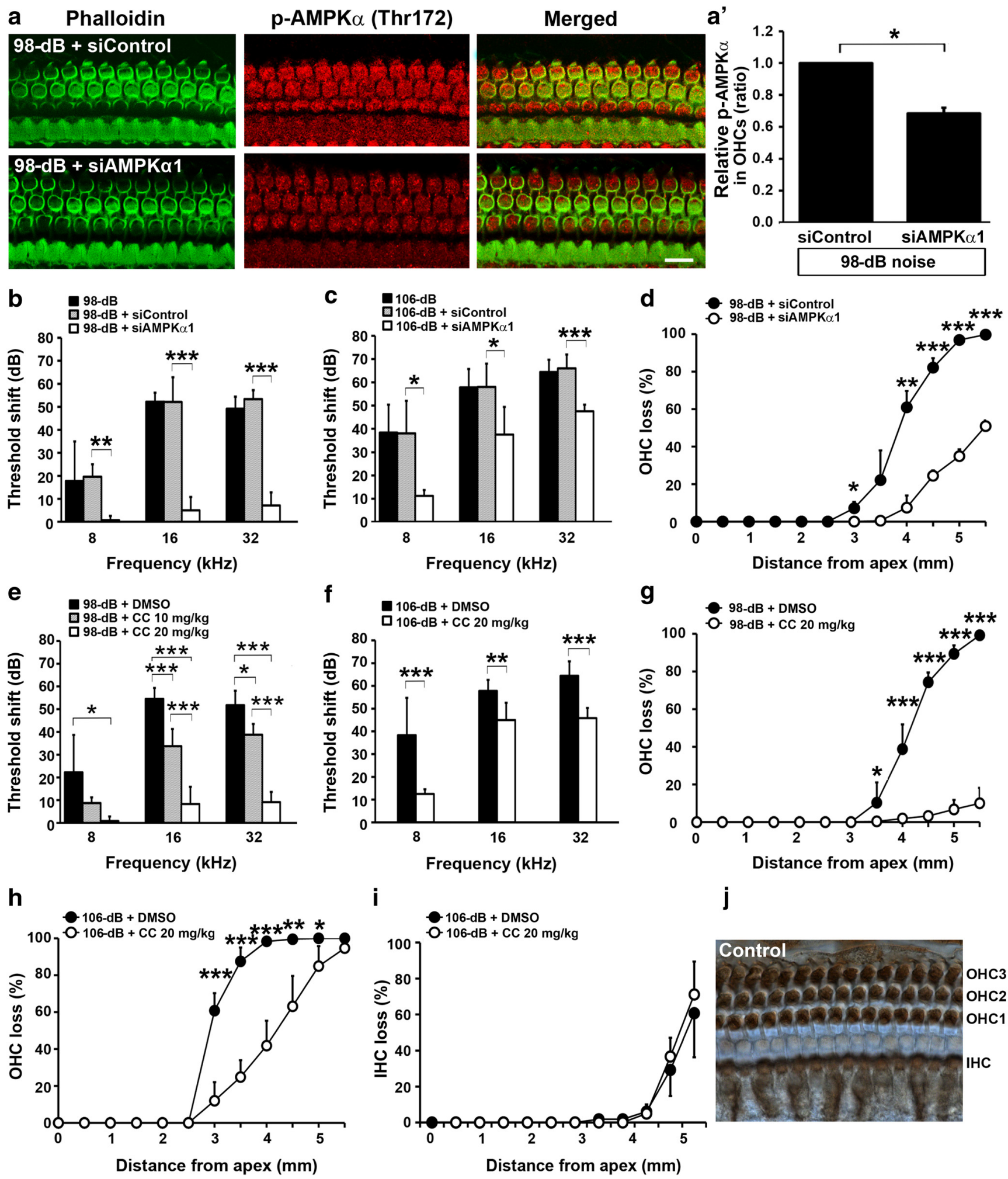

Figure 3. Inhibition of AMPK $\alpha 1$ via siRNA and compound ( protected against noise-induced hearing loss and outer hair cell loss. $\boldsymbol{a}, \boldsymbol{a}^{\prime}$, Pretreatment with siAMPK $\alpha 1$ decreased immunolabeling for $\mathrm{p}-\mathrm{AMPK} \alpha$ in $\mathrm{OHCs}$ compared with siControl treatment $1 \mathrm{~h}$ after $98 \mathrm{~dB}$ exposure; $n=3$. Representative images (a) were taken from the basal turn. Scale bar, $10 \mu \mathrm{m}$. $\boldsymbol{b}, \boldsymbol{c}$, siAMPK $\alpha 1$ pretreatment reduced $98 \mathrm{~dB}(\boldsymbol{b})$ and $106 \mathrm{~dB}(\boldsymbol{c})$ noise-induced permanent threshold shifts. $98 \mathrm{~dB}, n=18 ; 98 \mathrm{~dB}+$ siControl, $n=8 ; 98 \mathrm{~dB}+$ siAMPK $\alpha 1, n=7 ; 106 \mathrm{~dB}$, $n=6 ; 106 \mathrm{~dB}+$ siControl, $n=3 ; 106 \mathrm{~dB}+\operatorname{siAMPK} \alpha 1, n=4$. d, Noise-induced (98 dB) OHC loss was reduced by siAMPK $\alpha 1$ pretreatment; $n=3$. $\boldsymbol{e}$, Compound C treatment reduced $98 \mathrm{~dB}$ noise-induced permanent threshold shifts in a dose-dependent fashion. $98 \mathrm{~dB}+$ DMSO, $n=20 ; 98 \mathrm{~dB}+\mathrm{CC} 10 \mathrm{mg} / \mathrm{kg}, n=4 ; 98 \mathrm{~dB}+\mathrm{CC} 20 \mathrm{mg} / \mathrm{kg}, n=6 . f$, Compound C treatment $(20 \mathrm{mg} / \mathrm{kg}$ ) reduced $106 \mathrm{~dB}$ noise-induced permanent threshold shifts; $\boldsymbol{n}=6 . \boldsymbol{g}, \boldsymbol{h}$, Compound C treatment $(20 \mathrm{mg} / \mathrm{kg})$ decreased $98 \mathrm{~dB}(\boldsymbol{g})$ and $106 \mathrm{~dB}(\boldsymbol{h})$ noise-induced $0 \mathrm{HC}$ loss. $98 \mathrm{~dB}+$ DMSO $n=7 ; 98 \mathrm{~dB}+$ CC $20 \mathrm{mg} / \mathrm{kg}, n=6 ; 106 \mathrm{~dB}+\mathrm{DMSO}, n=3 ; 106 \mathrm{~dB}+$ CC $20 \mathrm{mg} / \mathrm{kg}, n=6$. $i$, Noise-induced IHC loss was unchanged by compound C treatment. $n=4 . j$, A representative image (basal turn) displays DAB-stained myosin VIla immunolabeling of sensory hair cells of a control mouse. Data are presented as the mean \pm SD. Data were collected $14 \mathrm{~d}$ after exposure, unless otherwise stated. ${ }^{* *} p<0.001,{ }^{* *} p<0.01,{ }^{*} p<0.05$. 
Table 1. Post hoc tests for data in Figure $3, b, c, e$, and $f$

\begin{tabular}{|c|c|c|c|}
\hline Noise (dB SPL) & Groups & Frequency (kHz) & $p$ value \\
\hline \multirow[t]{12}{*}{98} & \multirow[t]{3}{*}{ siControl vs siAMPK $\alpha 1$} & 8 & 0.009 \\
\hline & & 16 & $<0.001$ \\
\hline & & 32 & $<0.001$ \\
\hline & \multirow[t]{3}{*}{ DMSO vs CC 20 mg/kg } & 8 & 0.027 \\
\hline & & 16 & $<0.001$ \\
\hline & & 32 & 0.001 \\
\hline & \multirow[t]{3}{*}{ DMSO vs CC 10 mg/kg } & 8 & NA \\
\hline & & 16 & $<0.001$ \\
\hline & & 32 & 0.011 \\
\hline & \multirow[t]{3}{*}{ CC $10 \mathrm{mg} / \mathrm{kg}$ vs CC $20 \mathrm{mg} / \mathrm{kg}$} & 8 & NA \\
\hline & & 16 & 0.001 \\
\hline & & 32 & 0.001 \\
\hline \multirow[t]{6}{*}{106} & \multirow[t]{3}{*}{ siControl vs siAMPK $\alpha 1$} & 8 & 0.023 \\
\hline & & 16 & 0.05 \\
\hline & & 32 & $<0.001$ \\
\hline & \multirow[t]{3}{*}{ DMSO vs CC $20 \mathrm{mg} / \mathrm{kg}$} & 8 & $<0.001$ \\
\hline & & 16 & 0.006 \\
\hline & & 32 & 0.001 \\
\hline
\end{tabular}

NA, Not applicable.

AMPK $\alpha 1$ and AMPK $\alpha 2$ protein levels (Fig. $2 c$ ) and qRT-PCR assessing mRNA levels of AMPK $\alpha 1$ and AMPK $\alpha 2$ (data not shown) using total cochlear homogenates were unchanged between control and noise-exposed cochlear samples examined $1 \mathrm{~h}$ after noise exposure.

\section{Silencing AMPK $\alpha 1$ or treatment with pharmacological inhibitor compound $\mathrm{C}$ protects against noise-induced outer hair cell loss and permanent hearing loss}

To determine the contribution of AMPK $\alpha$ to NIHL, AMPK $\alpha 1$ siRNA ( $\operatorname{siAMPK} \alpha 1)$ was used. Three concentrations $(0.3,0.6$, and $0.9 \mu \mathrm{g}$ ) of siAMPK $\alpha 1$ were tested in preliminary in vivo experiments; $0.6 \mu \mathrm{g}$ was selected for use in this study due to silencing efficiency in hair cells. Seventy-two hours after intratympanic delivery of siAMPK $\alpha 1$, the $98 \mathrm{~dB}$ noise-induced elevation of immunolabeling for $\mathrm{p}-\mathrm{AMPK} \alpha$ in $\mathrm{OHCs}$ was attenuated by $30 \%$ compared with the OHCs of mice that received scrambled siRNA (siControl) examined $1 \mathrm{~h}$ after the noise exposure $\left(p=0.0127, t_{(2)}=8.781\right.$; Fig. $\left.3 a, a^{\prime}\right)$. However, Western blots for the analysis of p-AMPK $\alpha$ and total AMPK $\alpha 1$ showed no difference between siControl- and siAMPK $\alpha 1$ treated groups (data not shown). Furthermore, pretreatment with siAMPK $\alpha 1$ reduced noise-induced OHC loss measured $14 \mathrm{~d}$ after $98 \mathrm{~dB}$ exposure $\left(p=0.001, F_{(1,3)}=176.966\right.$; Fig. $\left.3 d\right)$. The reduction of OHC loss was to control levels at $3-3.5 \mathrm{~mm}$ $(p=0.028)$ and by $>55 \%$ at $4-5.5 \mathrm{~mm}(4 \mathrm{~mm}, p=0.004 ; 4.5$ $\mathrm{mm}, p<0.001 ; 5 \mathrm{~mm}, p<0.001 ; 5.5 \mathrm{~mm}, p<0.001)$ from the apex of the sensory epithelium. Consequently, auditory threshold shifts of the siAMPK $\alpha 1$-treated group recovered to near-baseline levels at $8 \mathrm{kHz}\left(p=0.009, F_{(2,33)}=5.418\right)$ and were attenuated from 50 to $10 \mathrm{~dB}$ at both $16 \mathrm{kHz}(p<0.001$, $\left.F_{(2,33)}=82.882\right)$ and $32 \mathrm{kHz}\left(p<0.001, F_{(2,33)}=135.791\right.$; Fig. $3 b)$. In addition, the siAMPK $\alpha 1$ pretreatment significantly reduced auditory threshold shifts $14 \mathrm{~d}$ after exposure to $106 \mathrm{~dB}$ noise by $30 \mathrm{~dB}$ at $8 \mathrm{kHz}\left(p=0.023, F_{(2,11)}=5.226\right)$, and by 20 $\mathrm{dB}$ at $16 \mathrm{kHz}\left(p=0.05, F_{(2,11)}=3.48\right)$ and $32 \mathrm{kHz}(p<0.001$, $F_{(2,11)}=21.23$; Fig. $\left.3 c\right)$.

Since silencing AMPK $\alpha 1$ protected against noise-induced hair cell loss and NIHL, we next examined the effects of compound C, a selective ATP-competitive inhibitor of AMPK. Based on the findings of previous studies (Shen et al., 2008), we tested two concentrations
(10 and $20 \mathrm{mg} / \mathrm{kg}$ ) in adult CBA/J mice. Our preliminary results showed that mice receiving five doses of either concentration maintained normal body weights and hearing thresholds. The fur of treated mice also appeared as shiny as that of control mice, and the mice displayed no overt signs of illness. Treatment with either concentration of compound $\mathrm{C}$ significantly reduced the auditory threshold shifts 2 weeks after a $98 \mathrm{~dB}$ exposure in a dose-dependent fashion at $8 \mathrm{kHz}\left(F_{(2,27)}=4.427, p=0.022\right), 16 \mathrm{kHz}\left(F_{(2,27)}=\right.$ $60.052, p<0.001)$, and $32 \mathrm{kHz}\left(F_{(2,27)}=44.294, p<0.001\right.$; Fig. $\left.3 e\right)$. Further analysis confirmed significant protection by pretreatment with either siAMPK $\alpha$ or compound C (for detailed statistical values, see Table 1). Since the higher dose of compound C (20 mg/kg) elicited greater protection, $\mathrm{OHC}$ loss was examined at this concentration. $\mathrm{OHC}$ loss remained $<10 \%$ throughout the basal region of the cochlea in compound C-treated mice $14 \mathrm{~d}$ after $98 \mathrm{~dB}$ exposure, in contrast to the vehicle (DMSO) group in which $10 \%, 40 \%, 90 \%$, and $100 \%$ OHC loss occurred at $3.5 \mathrm{~mm}(p=0.046), 4 \mathrm{~mm}(p<0.001)$, $4.5 \mathrm{~mm}(p<0.001), 5 \mathrm{~mm}(p<0.001)$, and $5.5 \mathrm{~mm}(p<0.001)$ from the apex, respectively $\left(p<0.001, F_{(1,10)}=53.51\right.$; Fig. $\left.3 g\right)$. Furthermore, treatment with compound $\mathrm{C}$ reduced $106 \mathrm{~dB}$-induced OHCloss by $20-50 \%$ at $4 \mathrm{~mm}(p<0.001), 4.5 \mathrm{~mm}(p=0.004)$, and $5 \mathrm{~mm}(p=0.041)$ from the apex $\left(p<0.001, F_{(1,10)}=53.51 ;\right.$ Fig. $\left.3 h\right)$; and attenuated auditory thresholds by 30,15 , and $20 \mathrm{~dB}$ at $8 \mathrm{kHz}$ $\left(p<0.001, t_{(8)}=-6.559\right), 16 \mathrm{kHz}\left(p=0.006, t_{(8)}=-3.651\right)$, and $32 \mathrm{kHz}\left(p=0.001, t_{(8)}=-5.22\right)$, respectively, measured $14 \mathrm{~d}$ after the exposure (Fig. $3 f$ ). However, treatment with compound $\mathrm{C}$ did not alter $106 \mathrm{~dB}$-noise-induced IHC loss (Fig. 3i).

\section{Silencing AMPK $\alpha 1$ or treatment with pharmacological inhibitor compound $\mathrm{C}$ prevents noise-induced loss of inner hair cell presynaptic ribbons and wave I amplitude}

To determine whether blockade of AMPK $\alpha 1$ activation by siRNA or compound C could attenuate noise-induced loss of IHC synaptic connections, we first quantified ribbons at $1 \mathrm{~h}$, and $1,3,7$, and $14 \mathrm{~d}$ after a $98 \mathrm{~dB}$ noise. Exposure to the noise significantly reduced synaptic ribbon counts by $40 \% 1 \mathrm{~h}$ after the exposure at $22 \mathrm{kHz}$ region $\left(p=0.005, t_{(8)}=-3.906\right)$. The ribbon loss remained stable and significantly lower than those of unexposed controls for at least $14 \mathrm{~d}$, the latest time measured (Fig. 4d). We also identified functional IHC synapses as juxtaposed presynaptic ribbons and postsynaptic glutamate receptors examined $1 \mathrm{~h}$ and $14 \mathrm{~d}$ after the $98 \mathrm{~dB}$ noise exposure. In agreement with the loss of ribbons, the synapses were also reduced at $22 \mathrm{kHz}\left(p=0.022, t_{(8)}=-2.848\right.$; Fig. $\left.4 e\right)$, but there was no difference between loss of ribbons and synapses. Furthermore, a $106 \mathrm{~dB}$ noise exposure induced a greater amount of synaptic ribbon loss at the high-frequency regions $\left(22 \mathrm{kHz}: F_{(2,9)}=57.412, p<0.001 ; 32 \mathrm{kHz}: F_{(2,8)}=16.561\right.$, $p=0.02)$ after the exposure evaluated at $1 \mathrm{~h}$, which also did not recover $14 \mathrm{~d}$ after the exposure (Fig. $4 b$ ). In addition, the $106 \mathrm{~dB}$ noise exposure reduced functional IHC synapses at high-frequency regions $1 \mathrm{~h}$ and $14 \mathrm{~d}$ after exposure (control vs $1 \mathrm{~h}$ after $106 \mathrm{~dB}$ noise exposure: $F_{(2,9)}=57.398, p<0.001$; control vs $14 \mathrm{~d}$ after $106 \mathrm{~dB}$ noise exposure: $F_{(2,8)}=16.561$, $p=0.001$; Fig. $4 c$ ). Further analysis revealed that the differences between the control group and $1 \mathrm{~h}$ after $106 \mathrm{~dB}$ noise exposure groups at $22 \mathrm{kHz}(p<0.001)$ and $32 \mathrm{kHz}(p=$ $0.001)$ were significant. The loss of synapses at $22 \mathrm{kHz}$ at $14 \mathrm{~d}$ was less than those lost at $1 \mathrm{~h}$ after a $106 \mathrm{~dB}$ noise exposure $(p=0.0485$; Fig. $4 c)$. Additionally, we observed a difference only in the level of noise-induced presynaptic ribbon loss and the number of functional synapses lost at $1 \mathrm{~h}$ after the $106 \mathrm{~dB}$ noise exposure at $32 \mathrm{kHz}$, at which time there was a greater loss 

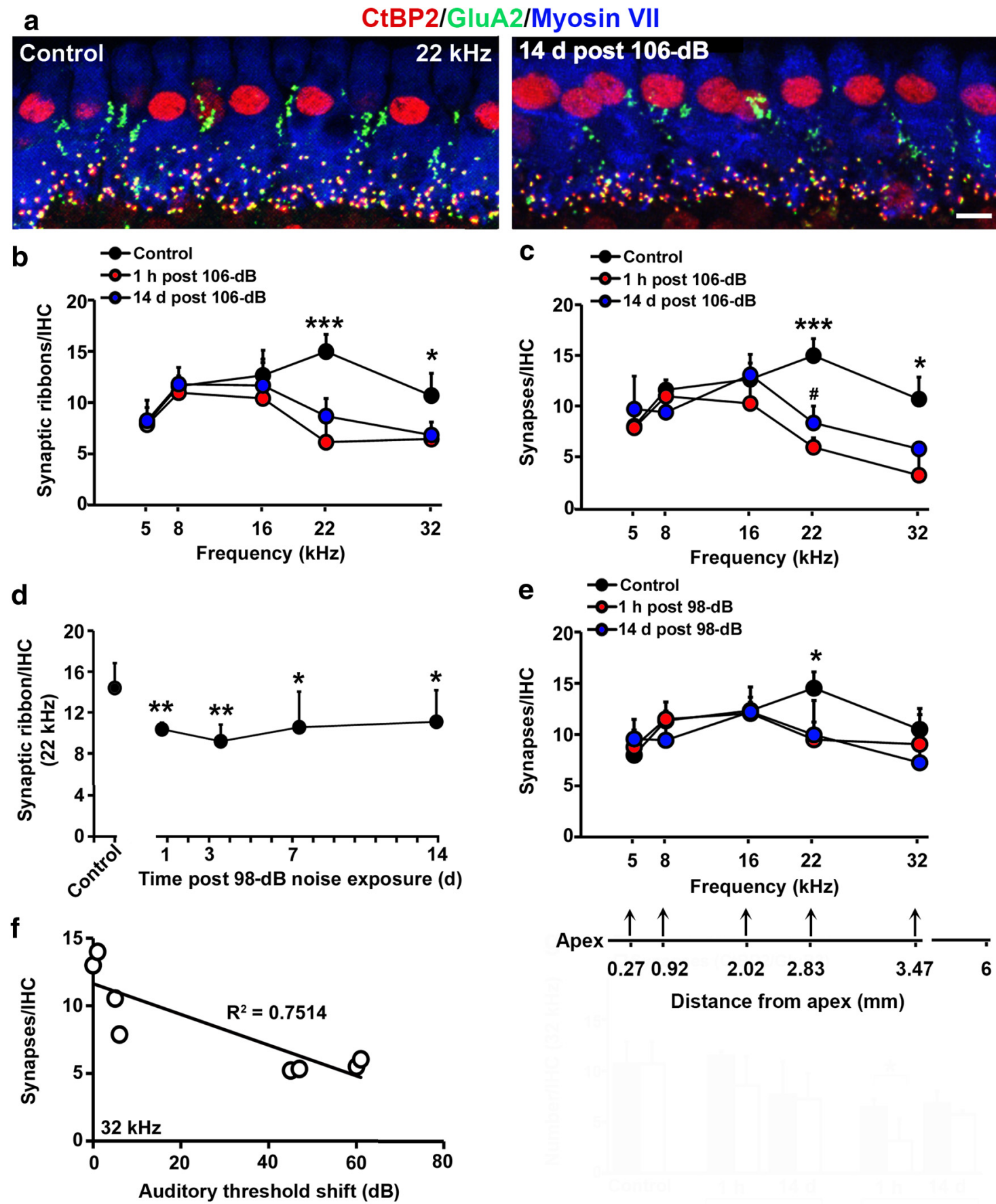

Figure 4. Noise-induced synapse loss partially recovers $14 \mathrm{~d}$ after exposure. $\boldsymbol{a}$, Representative images of $106 \mathrm{~dB}$ noise-induced IHC synaptic ribbon and glutamate receptor loss at $22 \mathrm{kHz}$. Blue, myosin-VIla labeled IHCs; red, CtBP2-labeled synaptic ribbons; green, GluA2-labeled postsynaptic terminals. Scale bar, $10 \mu \mathrm{m} . \boldsymbol{b}$, Ribbons per IHC were reduced $1 \mathrm{~h}$ and $14 \mathrm{~d}$ after $106 \mathrm{~dB}$ exposure at 22 and $32 \mathrm{kHz}$ compared with unexposed controls. c, Synapses (juxtaposed ribbons and glutamate receptors) per IHC were reduced $1 \mathrm{~h}$ and $14 \mathrm{~d}$ after $106 \mathrm{~dB}$ exposure at 22 and $32 \mathrm{kHz}$ compared with controls. Synapses at $22 \mathrm{kHz}$ significantly increased at $14 \mathrm{~d}$ compared with $1 \mathrm{~h}$ after exposure. $d$, Ribbons per $1 \mathrm{HC}$ at $22 \mathrm{kHz}$ were reduced $1 \mathrm{~h}$ and maintained $14 \mathrm{~d}$ after $98 \mathrm{~dB}$ exposure compared with controls. Since there are no changes in the synaptic ribbons within $14 \mathrm{~d}$ in normal control adult CBA/J mice (without noise exposure), synaptic ribbons at each time point after the noise exposure were compared with a single control group analyzed without noise exposure. , Synapses per IHC at $22 \mathrm{kHz}$ were reduced $1 \mathrm{~h}$ and $14 \mathrm{~d}$ after $98 \mathrm{~dB}$ exposure compared with controls. The distance along the cochlear duct that correlated with the frequency regions is indicated below e. $\boldsymbol{f}$, Synapse number negatively correlates with auditory threshold shifts $14 \mathrm{~d}$ after exposure. $n=8$. Data are presented as the mean $\pm S D$. ${ }^{* *} p<0.001,{ }^{* *} p<0.01,{ }^{*} / \# p<0.05$. Control, $n=7 ; 1 \mathrm{~h}$ after $106 \mathrm{~dB}, n=4 ; 14 \mathrm{~d}$ after $106 \mathrm{~dB}, n=4 ; 1 \mathrm{~h}$ after $98 \mathrm{~dB}, n=5 ; 14 \mathrm{~d}$ after $98 \mathrm{~dB}, n=5 .{ }^{*}$ Control vs $14 \mathrm{~d}$ postexposure; $\# 14 \mathrm{~d}$ vs $1 \mathrm{~h}$.

of synapses $\left(p=0.028, t_{(5)}=3.052\right)$. However, the number of functional synapses recovered to a level comparable to that of the presynaptic ribbons by $14 \mathrm{~d}$ after exposure. Furthermore, to confirm whether synapses with juxtaposed CtBP2 and GluA2 indeed represented functional synapses, we conducted regression analysis that showed a correlation between synapse number and auditory function $\left(R^{2}=0.7514\right.$; i.e., more synapses correlated with good hearing function; Fig. $4 f$ ).

The effect of inhibition of AMPK by pretreatment with siAMPK $\alpha 1$ and compound $\mathrm{C}$ on the protection of synaptic ribbons was examined $1 \mathrm{~h}$ and $14 \mathrm{~d}$ after a $106 \mathrm{~dB}$ noise exposure, and $\mathrm{ABR}$ wave I amplitudes were measured at $14 \mathrm{~d}$ after 


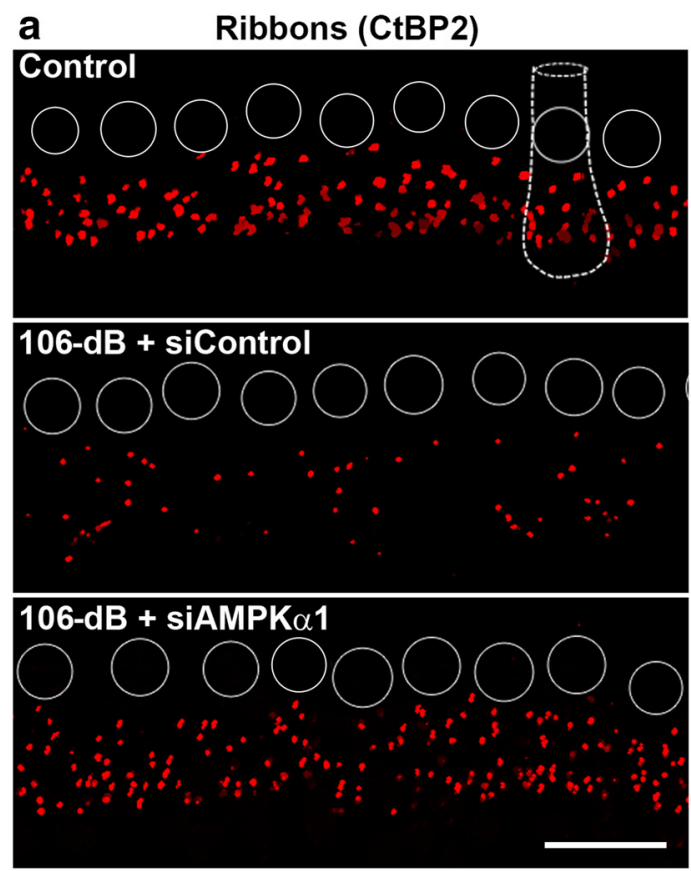

c
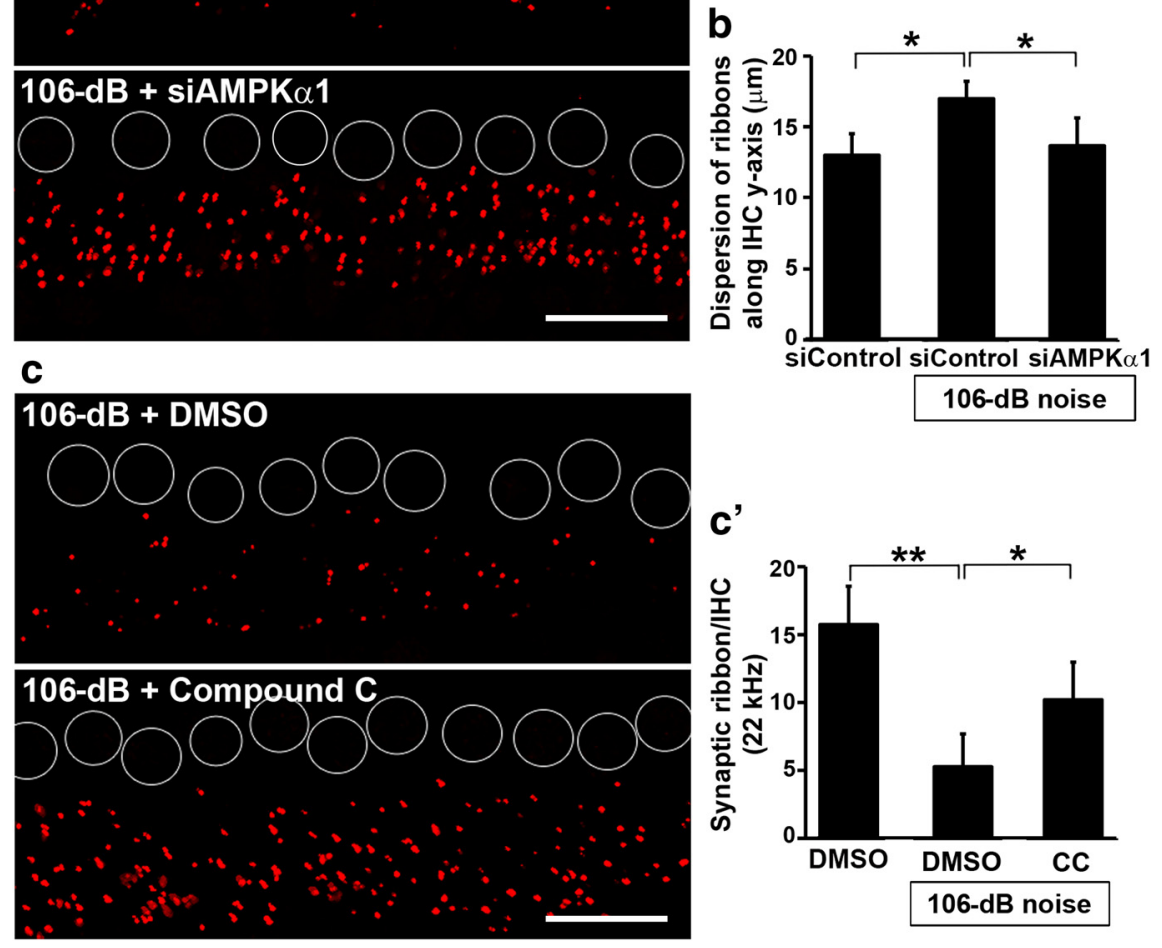

Figure 5. Inhibition of AMPK-attenuated noise-induced inner hair cell synaptic ribbon loss at $22 \mathrm{kHz} 1 \mathrm{~h}$ after $106 \mathrm{~dB}$ noise exposure. $\boldsymbol{a}$, Noise-induced loss of immunolabeled CtBP2 (red) in IHCs was prevented by pretreatment with siAMPK $\alpha 1$. The immunolabeling for $\mathrm{CtBP} 2$ in IHC nuclei was removed from the figure, and the nuclei are illustrated with circles for clear visualization of the synaptic ribbons. A rough outline of an IHC is indicated by dashed lines. $\boldsymbol{a}^{\prime}$, Quantification of CtBP2-immunolabeled ribbon particles in IHCS confirmed that noise-induced reduction of ribbons was partially prevented with siAMPK $\alpha 1$ pretreatment; $n=4 . \boldsymbol{b}, 106 \mathrm{~dB}$ noise-induced dispersion of CtBP2-immunolabeled ribbons along the $\mathrm{IHC} y$-axis returned to baseline levels with siAMPK $\alpha 1$ pretreatment; $n=4$. c, Compound ( treatment $(20 \mathrm{mg} / \mathrm{kg})$ prevented the noise-induced loss of CtBP2immunolableled (red) synaptic ribbons in IHCs. $c^{\prime}$, Quantification of CtBP2-immunolabeled ribbons in IHCs confirmed significant increases with compound C ( $20 \mathrm{mg} / \mathrm{kg})$ treatment; $n=4$. Representative images $(\boldsymbol{a}, \boldsymbol{c})$ were taken from the $22 \mathrm{kHz}$ region. Scale bar, $10 \mu \mathrm{m}$. Data $\left(\boldsymbol{a}^{\prime}, \boldsymbol{b}, \boldsymbol{c}^{\prime}\right)$ are presented as the mean $\pm \mathrm{SD} .{ }^{* * *} p<0.001,{ }^{* *} p<0.01,{ }^{*} p<0.05$.

exposure. One hour after exposure, CtBP2-immunolabeled synaptic ribbons of IHCs decreased on surface preparations in the $22 \mathrm{kHz}$ region (Fig. $5 a$, corresponding to a location $3 \mathrm{~mm}$ from the apex) by $70 \%$ compared with unexposed controls $\left(F_{(2,13)}=4.034, p<0.001\right.$; Fig. $\left.5 a^{\prime}\right)$. Pretreatment with siAMPK $\alpha 1$ prevented the loss of synaptic ribbons by $50 \%$ $\left(F_{(2,13)}=4.034, p<0.001\right.$; Fig. $\left.5 a^{\prime}\right)$. Additionally, noise exposure dispersed the synaptic ribbons along the IHC $y$-axis $(p=0.017)$, which was prevented by siAMPK $\alpha 1$ pretreatment $\left(F_{(2,9)}=7.03, p=0.014\right.$; Fig. $\left.5 b\right)$. Furthermore, significant protection with siAMPK $\alpha 1$ pretreatment against synaptic ribbon loss was still evident $14 \mathrm{~d}$ after noise exposure at higherfrequency regions of the cochlea corresponding to $22 \mathrm{kHz}$ $\left.t_{(13)}=2.16, p=0.0492\right)$ and $32 \mathrm{kHz}$ $\left(t_{(12)}=2.67, p=0.02\right.$; Fig. $\left.6 a\right)$. Additionally, treatment with compound $\mathrm{C}$ at $20 \mathrm{mg} / \mathrm{kg}$ also prevented noise-induced loss of synaptic ribbons in IHCs (Fig. $5 c$ ) $1 \mathrm{~h}$ after $106 \mathrm{~dB}$ noise exposure $\left(F_{(2,11)}\right.$ $=15.072, p=0.04)$ by $50 \%$ compared with DMSO treatment ( $p=0.001$; Fig. $\left.5 c^{\prime}\right)$.

Since ABR wave I amplitudes indicate the activity of the auditory nerve, we measured the amplitude of $A B R$ wave I. The amplitudes were only examined at $8 \mathrm{kHz}$ (1 $\mathrm{mm}$ from the apex) to avoid regions of outer hair cell loss (Müller et al., 2005). Fourteen days after exposure to $106 \mathrm{~dB}$ noise, the noise-induced decrease in wave I amplitudes was significantly elevated at $8 \mathrm{kHz}$ either by pretreatment with siAMPK $\alpha$ (siAMPKal vs siControl: $F_{(1,6)}$ $=8.489, p=0.027)$ or compound $\mathrm{C}(\mathrm{CC}$ vs DMSO: $\left.F_{(1,10)}=7.498, p=0.021\right)$. Further analysis confirmed significant elevation of wave I amplitude at 90 and $100 \mathrm{~dB}$ stimulus (Fig. $6 b, c$; for statistical data, see Table 2).

\section{Noise exposure increases LKB1 activity} in cochlear cells

LKB1 serves as the primary upstream kinase of AMPK; therefore, we examined p-LKB1, a signal for nuclear translocation of the activated LKB1 complex. Immunolabeling for $\mathrm{p}$-LKB1 was increased in the nuclei and cytosol of OHCs, IHCs, Deiters and pillar cells, SGNs, the basal cells of the stria vascularis, and the fibrocytes of the spiral ligament $1 \mathrm{~h}$ following a $98 \mathrm{~dB}$ noise exposure (Fig. $7 a$ ). The increased immunolabeling for p-LKB1 in the cytosol of OHCs was quantified from surface preparations, which showed a more than twofold increase in basal OHCs $1 \mathrm{~h}$ after $98 \mathrm{~dB}$ exposure compared with unexposed controls $\left(p=0.005, t_{(3)}=7.585\right)$. In addition, immunoblots of total cochlear homogenates showed a single band for p-LKB1 at the molecular weight of 54 $\mathrm{kDa}$, which was significantly increased $1 \mathrm{~h}$ after the exposure $\left(p=0.017, t_{(4)}=3.947\right)$. No change was detected in total LKB1 levels (Fig. $7 c, c^{\prime}$ ).

Pretreatment with LKB1 siRNA diminishes noise-elevated p-AMPK $\alpha$ and reduces noise-induced outer hair cell loss, synaptopathy, and hearing loss

We also evaluated the role of LKB1 in NIHL using siRNAsilencing techniques. Pretreatment with $0.6 \mu \mathrm{g}$ of siLKB1 reduced $98 \mathrm{~dB}$ noise-elevated immunolabeling for p-LKB1 by $25 \%$ in OHCs at basal turn compared with groups treated with scrambled siRNA (siControl: $p=0.014, t_{(4)}=-4.155$ ). Pretreatment with siLKB1 also significantly reduced the $98 \mathrm{~dB}$ noise-induced immunolabeling for p-AMPK $\alpha$ in OHCs at basal turn (Fig. $8 a$ ) by 

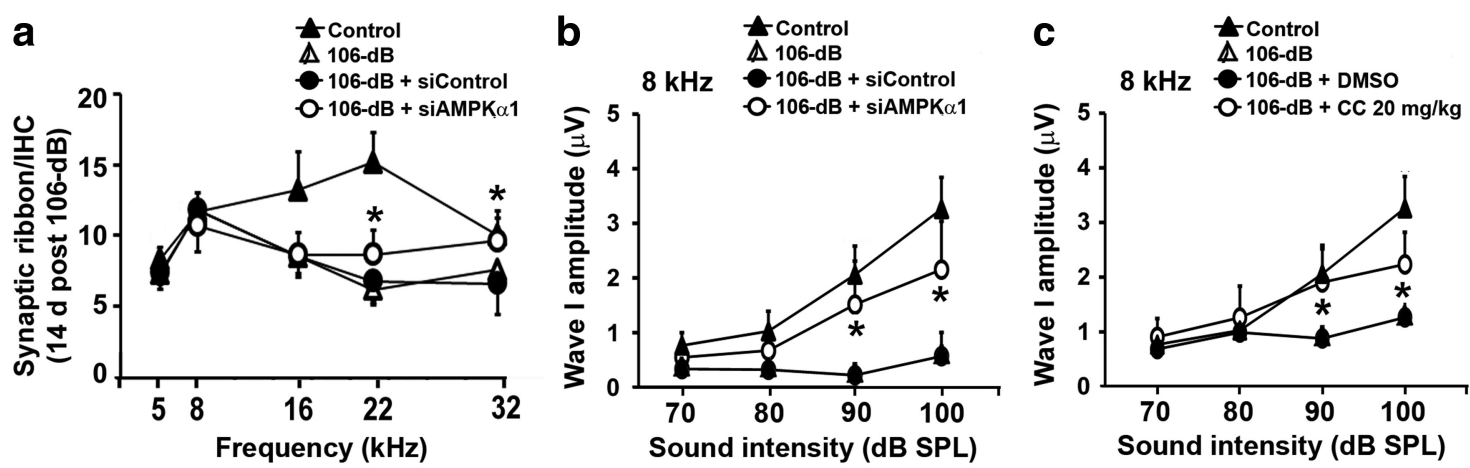

Figure 6. Inhibition of AMPK protected from noise-induced synaptopathy $14 \mathrm{~d}$ after $106 \mathrm{~dB}$ exposure. $\boldsymbol{a}, 106 \mathrm{~dB}$ noise-induced synaptic ribbon loss remained significantly lower than unexposed controls at 16, 22, and $32 \mathrm{kHz} 14 \mathrm{~d}$ after the exposure. Pretreatment with siAMPK $\alpha 1$ increased the number of synaptic ribbons at 22 and $32 \mathrm{kHz}$ regions of the sensory epithelium. Control, $n=4$; $106 \mathrm{~dB}, n=5 ; 106 \mathrm{~dB}+$ siControl, $n=5 ; 106 \mathrm{~dB}+$ siAMPK $\alpha 1, n=5$. $\boldsymbol{b}$, Pretreatment with siAMPK $\alpha 1$ significantly elevated $106 \mathrm{~dB}$ noise-induced reduction in wave I amplitude at sound intensities of 90 and $100 \mathrm{dBSPL}$ at $8 \mathrm{kHz}$. Control, $n=10 ; 106 \mathrm{~dB}+$ siControl, $n=8 ; 106 \mathrm{~dB}+\operatorname{siAMPK} \alpha 1, n=4$. $c$, The decrease in wave lamplitude after $106 \mathrm{~dB}$ noise was prevented by compound C treatment (20 mg/kg) at sound intensities of 90 and $100 \mathrm{~dB} \mathrm{SPL}$ at $8 \mathrm{kHz}$. Control, $n=10 ; 106 \mathrm{~dB}+$ DMSO, $n=14 ; 106 \mathrm{~dB}+C\left(20 \mathrm{mg} / \mathrm{kg}, n=4\right.$. Data are presented as the mean \pm SD. ${ }^{*} p<$ 0.05 was $106 \mathrm{~dB}+$ siControl vs $106 \mathrm{~dB}+$ siAMPK $\alpha 1$ or $106 \mathrm{~dB}+$ DMSO vs $106 \mathrm{~dB}+\mathrm{CC} 20 \mathrm{mg} / \mathrm{kg}$.

Table 2. Post hoc tests for data in Figure 6, b and c

\begin{tabular}{llcc}
\hline $\begin{array}{l}\text { Frequency } \\
(\mathrm{kHz})\end{array}$ & Groups & $\begin{array}{l}\text { Sound intensity } \\
(\mathrm{dB})\end{array}$ & $p$ value \\
\hline 8 & $106 \mathrm{~dB}+$ siAMPK $\alpha$ vs $106 \mathrm{~dB}+$ siControl & 90 & 0.027 \\
& & 100 & 0.038 \\
& $106 \mathrm{~dB}+\mathrm{CC}(20 \mathrm{mg} / \mathrm{kg})$ vs $106 \mathrm{~dB}+$ DMSO & 90 & 0.035 \\
& & 100 & 0.023 \\
\hline
\end{tabular}

$20 \%\left(p=0.0451, t_{(2)}=4.5466\right.$; Fig. $\left.8 a^{\prime}\right)$, indicating that LKB1 phosphorylates AMPK $\alpha 1$. However, Western blots for analysis of p-AMPK $\alpha$ and total AMPK $\alpha 1$ from homogenates of whole cochleae showed no changes between siControl- and siLKB-treated groups (data not shown).

Furthermore, siLKB1 pretreatment completely prevented $98 \mathrm{~dB}$ noise-induced $\mathrm{OHC}$ loss at $4 \mathrm{~mm}(p=0.013)$, and significantly reduced loss by $50 \%$ at $4.5 \mathrm{~mm}(p=0.003)$ and $5 \mathrm{~mm}(p<0.001)$ from the apex $\left(p<0.001, F_{(1,12)}=21.618 ;\right.$ Fig. $\left.8 c\right)$. Subsequently, 98 $\mathrm{dB}$ noise-induced auditory threshold shifts were reduced from $15 \mathrm{~dB}$ to baseline levels at $8 \mathrm{kHz}$, and from 40 to $50 \mathrm{~dB}$ to $5 \mathrm{~dB}$ at both 16 $\mathrm{kHz}\left(p<0.001, t_{(8)}=7.246\right)$ and $32 \mathrm{kHz}\left(p<0.001, t_{(8)}=10.695\right)$ $14 \mathrm{~d}$ after the exposure (Fig. $8 b$ ). Unfortunately, siLKB treatment did not significantly attenuate $106 \mathrm{~dB}$ noise-induced hearing loss (Fig. $8 d$ ), but it protected against the reduction in ABR wave I amplitudes caused by $106 \mathrm{~dB}$ noise exposure. The height of ABR wave I amplitudes was restored to baseline levels for a $70 \mathrm{~dB}$ stimulus $\left(F_{(2,27)}=\right.$ 51.786, $p=0.004)$ and an $80 \mathrm{~dB}$ stimulus $\left(F_{(2,29)}=41.782, p<\right.$ 0.001 ) at $8 \mathrm{kHz}$ (Fig. $8 e$ ). Moreover, we counted synaptic ribbons $1 \mathrm{~h}$ after $106 \mathrm{~dB}$ noise exposure. Since $106 \mathrm{~dB}$ noise exposure resulted in the loss of synaptic ribbons at high frequencies (Fig. 4b), we counted synaptic ribbons only at 22 and $32 \mathrm{kHz}$. In agreement with the results of siAMPK $\alpha$ treatment, pretreatment with siLKB1 also prevented noise-induced loss of synaptic ribbons $\left(F_{(2,9)}=29.044, p<0.001\right)$, which increased from five to eight ribbons per IHC (siControl vs 106 $\mathrm{dB}$ plus siControl, $p<0.001 ; 106 \mathrm{~dB}$ plus siControl vs $106 \mathrm{~dB}$ plus siLKB1, $p=0.044$; Fig. $8 f$ ).

\section{Discussion}

AMPK activity contributes to the pathogenesis of noise-induced hearing loss by mediating loss of outer hair cells and inner hair cell synaptic ribbons

Our results demonstrate that exposure to traumatic levels of noise leads to sustained AMPK activation, resulting in outer hair cell death and cochlear synaptopathy with subsequent
NIHL. Immunoreactivity of p-AMPK $\alpha$ on both surface preparations and cochlear sections are in agreement, showing that immunolabeling for $\mathrm{p}$-AMPK $\alpha$ increases in sensory hair cells at the basal turn in a noise intensity-dependent manner. In contrast, immunoblots were generated from cochlear epithelial tissue homogenates that contain multiple cochlear cell types. Therefore, changes in $\mathrm{p}-\mathrm{AMPK} \alpha$ in the basal sensory hair cells are diluted by other cochlear cell types, such as supporting cells and spiral ganglion cells, in which the levels of p-AMPK $\alpha$ are unchanged. It may seem surprising that pretreatment with siAMPK $\alpha 1$ reduces $98 \mathrm{~dB}$-induced threshold shifts by $80 \%$ at both 16 and $32 \mathrm{kHz}$, with only a modest $30 \%$ reduction in noise-elevated $\mathrm{p}-\mathrm{AMPK} \alpha$ levels in OHCs. This suggests that a partial inhibition of AMPK $\alpha 1$ that occurs specifically in OHCs is sufficient for the prevention of NIHL. Treatment with the pharmacological AMPK inhibitor compound $\mathrm{C}$ provides even greater reduction of noise-induced $\mathrm{OHC}$ loss. This is logical, since compound $\mathrm{C}$ inhibits the phosphorylation of both $\alpha 1$ and $\alpha 2$ isoforms of AMPK, while AMPK $\alpha$ siRNA targets only the $\alpha 1$ isoform. Furthermore, our results are in line with those from a recent report (McKay et al., 2015) showing that precise genetic reduction of the enzyme AMPK can provide rescue from deafness in a model of profound mitochondrial genetic nonsyndromic hearing loss. Still, in our study neither treatment was fully protective from $106 \mathrm{~dB}$ noise-induced hearing loss and OHC loss, suggesting that such a high-level exposure may trigger additional cell death pathways and that pharmacological protection has to be directed at multiple targets. As a case in point, we have shown that the inhibition of noise-induced apoptosis in OHCs shifts the predominant cell death pathway to necrosis (Zheng et al., 2014).

Our results are in agreement with the notion that cochlear pathology is noise intensity dependent, not only for OHC loss, but also for the degree of loss of IHC presynaptic ribbons and functional synapses, with $106 \mathrm{~dB}$ noise exposure being more severe than $98 \mathrm{~dB}$ noise exposure. Functional synapses can be visualized by the juxtaposition of presynaptic ribbons (immunolabeling for CtBP2 protein) and postsynaptic terminals (immunolabeling for Glu2A protein). Our results confirm that the remaining number of functional synapses correlates with preserved auditory function. Although noise-induced loss of presynaptic ribbons remains unchanged over time, the loss of functional 
a

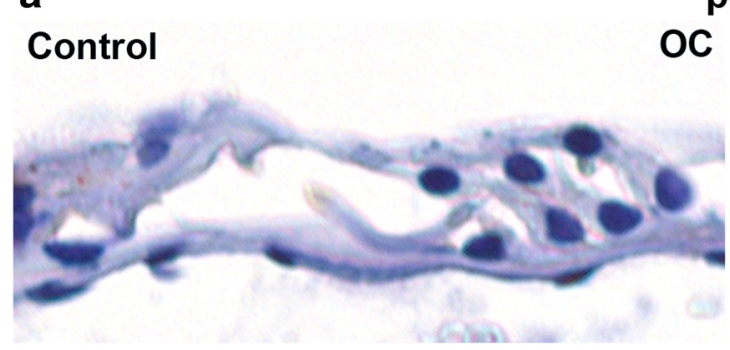

p-LKB1 (Ser428) / Hematoxylin

OC +7 TIN SGN
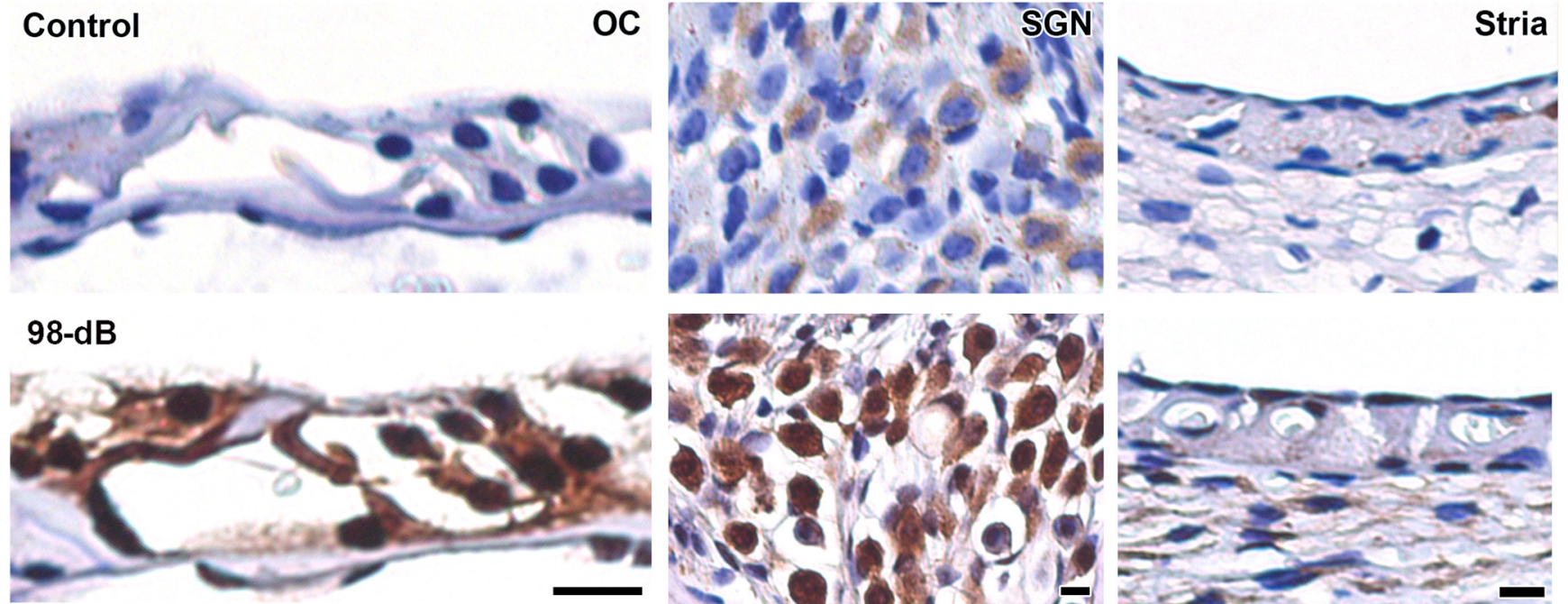

b

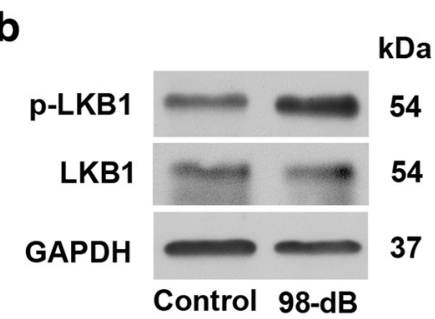

$\mathbf{b}^{\prime}$

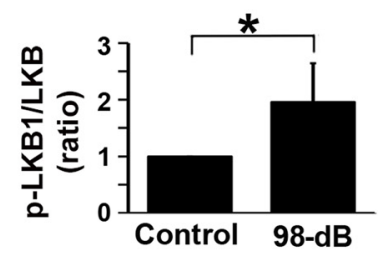

Figure 7. Noise exposure increased p-LKB1 in the cochlea. $\boldsymbol{a}$, Cochlear sections showed increased DAB-stained immunolabeling of p-LKB1 (brown) in the cytosol and nuclei of OHCs, IHCS, and supporting cells of the organ of Corti (OC), SGNs, basal cells of the stria vascularis, and fibrocytes of the spiral ligament (Stria) $1 \mathrm{~h}$ after $98 \mathrm{~dB}$ exposure compared with unexposed controls. Representative images were taken from the basal turn. Scale bar, $10 \mu \mathrm{m} . \boldsymbol{b}, \boldsymbol{b}^{\prime}$, Western blots using total cochlear homogenates showed increased p-LKB1 $1 \mathrm{~h}$ after $98 \mathrm{~dB}$ exposure compared with unexposed controls. GAPDH served as the sample loading control; $n=5$. Data are presented as the mean \pm SD. ${ }^{*} p<0.05$.

synapses is initially more severe than presynaptic ribbon loss. The number of functional synapses recovers over time to levels comparable to the number of initially remaining presynaptic ribbons, suggesting that postsynaptic nerve terminals may be able to reestablish connections with the remaining presynaptic ribbons (Wan et al., 2014; Liberman and Liberman, 2015). Additionally, our results on noise-induced synaptic ribbon dispersion examined at $1 \mathrm{~h}$ after noise exposure are in line with the previous observation indicating a disruption in the juxtaposition of presynaptic and postsynaptic terminals resulting in nonfunctional synapses (Liberman and Liberman, 2015). The prevention of cochlear synaptopathy by the inhibition of AMPK (via siAMPK $\alpha 1$ or compound C) is supported not only by attenuation of the loss of IHC ribbons and synapses, but also by diminution of the dispersion of synaptic ribbons. Furthermore, noise-induced reduction of ABR wave I amplitudes is also prevented by the inhibition of AMPK, suggesting the preservation of neuron firing.

Based on cochlear frequency maps, the area coding to $8 \mathrm{kHz}$ is located $\sim 1 \mathrm{~mm}$ from the apex of the cochlear sensory epithelium (Chen and Fechter, 2003; Müller et al., 2005). In line with our previous reports, we observed $\sim 40 \mathrm{~dB}$ threshold shifts at $8 \mathrm{kHz}$ after $106 \mathrm{~dB}$ noise exposure, but without losses of OHCs and ribbon synapses in that region. This may be due, in part, to the fused or collapsed stereocilia (Hu et al., 2002). Our results showing attenuation of NIHL by inhibition of AMPK activation via silencing or pharmacological inhibitor compound C differ from the findings with AMPK $\alpha$ knock-out mice previously reported (Föller et al., 2012). The difference between results following the silencing of AMPK $\alpha$ and the knockout of AMPK $\alpha$ points to the intrinsic disparities between the two methods of inhibition, as siRNA silencing transiently inhibits the expression of a gene, while a knockout eliminates gene function for the entire lifespan of the animal. A partial reduction of AMPK, modeled by silencing and pharmacological inhibition, may prevent the noise-induced imbalance of AMPK $\alpha$ signaling, whereas knockout of AMPK $\alpha$ may alter other molecular events, such as changes in BK channels, which may exacerbate hearing loss (Föller et al., 2012). In addition, our current study highlights a pathological function of the activation of AMPK in sensory hair cells in response to traumatic noise insults, which is contradictory to the traditional prosurvival view of AMPK. We can postulate that the role of AMPK varies with noise intensity. When noise levels cause temporary threshold shifts, AMPK may promote cell preservation through its energy-conserving downstream pathways, such as autophagy (Yuan et al., 2015). However, exposure to noise that causes permanent hearing loss resulted in sustained activation of AMPK, which may upregulate autophagy to eliminate the irreparably damaged cells or lead to mitochondrial dysfunction (VicenteTorres and Schacht, 2006; Chen et al., 2013). Determining the balance between AMPK activation and inhibition, and identifying the key timing or circumstances in which AMPK switches from a protective to a pathological function may be key to designing future therapies.

Finally, the concept that LKB1 mediates the contribution of AMPK to the progression of NIHL is supported by our results showing pretreatment with siLKB1-diminished immunolabeling for $\mathrm{p}-\mathrm{AMPK} \alpha$. Although the siLKB1 pretreatment reduced p-AMPK $\alpha$ by only $20 \%$, its reduction was similar to that detected 

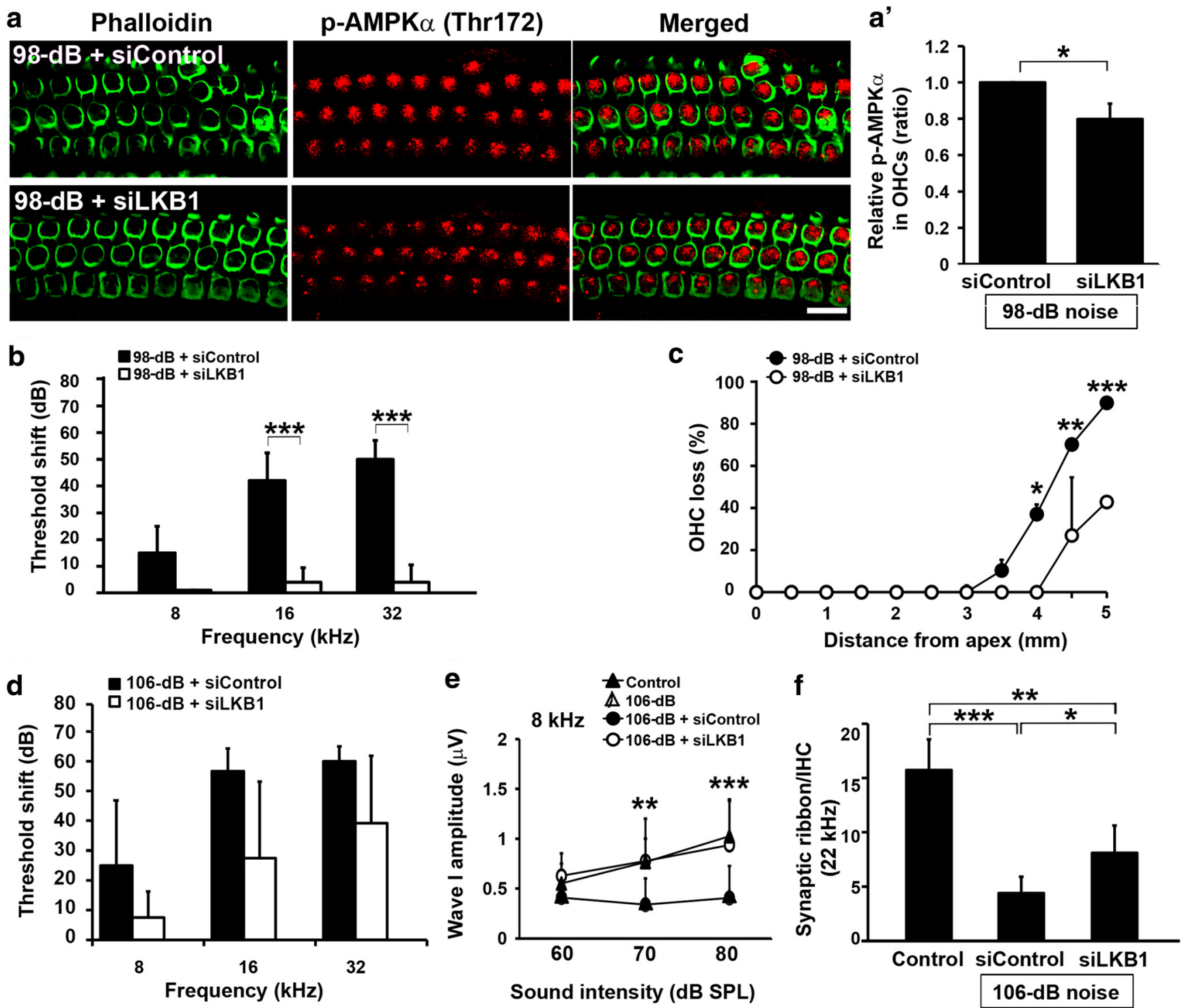

Figure 8. Inhibition of LKB1 reduced noise-induced P-AMPK $\alpha$ in outer hair cells, auditory threshold shifts, and loss of outer hair cells and inner hair cell synaptic ribbons. $\boldsymbol{a}$, Pretreatment with siLKB1 decreased p-AMPK $\alpha$ immunolabeling (red) in OHCs (green) $1 \mathrm{~h}$ after $98 \mathrm{~dB}$ exposure. Representative images were taken from the basal turn. Scale bar, $10 \mu \mathrm{m}$. $\boldsymbol{a}^{\prime}$, Quantification of p-AMPK $\alpha$ immunolabeling confirms a significant 20\% decrease in silKB1-treated cochleae $1 \mathrm{~h}$ after $98 \mathrm{~dB}$ noise exposure; $n=3$. $\boldsymbol{b}$, Pretreatment with silKB1 reduced $98 \mathrm{~dB}$ noise-induced threshold shifts at 16 and $32 \mathrm{kHz} 14 \mathrm{~d}$ after the exposure; $n=5$. c, Quantitative analysis of $\mathrm{OHCs}$ revealed significant protection from $0 \mathrm{HC}$ loss $14 \mathrm{~d}$ after the exposure with siLKB1 pretreatment. $98 \mathrm{~dB}+$ siControl, $n=12 ; 98 \mathrm{~dB}+$ siLKB1, $n=3$. d, Pretreatment with siLKB1 did not attenuate $106 \mathrm{~dB}$ noise-induced threshold shifts at 16 and $32 \mathrm{kHz} 14 \mathrm{~d}$ after the exposure; $n=6$. $\boldsymbol{e}$, Pretreatment with siLKB1 recovered wave I amplitudes at $8 \mathrm{kHz}$. Control, $n=10 ; 106 \mathrm{~dB}+$ siControl, $n=11 ; 106 \mathrm{~dB}+$ siLKB1, $n=6 .{ }^{*} 106$ $\mathrm{dB}+$ siControl vs $106 \mathrm{~dB}+$ siLKB1. $\boldsymbol{f}$, Pretreatment with siLKB1 increased the CtBP2 immunolabeled synaptic ribbons in IHCs $1 \mathrm{~h}$ after $106 \mathrm{~dB}$ exposure; $n=4$. Data $\left(\boldsymbol{a}^{\prime}\right.$ to $\left.\boldsymbol{f}\right)$ are presented as the mean $\pm \mathrm{SD}$. ${ }^{* * *} p<0.001,{ }^{* *} p<0.01,{ }^{*} p<0.05$.

with siAMPK $\alpha$ pretreatment, making a strong case for the phosphorylation of AMPK by LKB1 following noise exposure.

\section{Changes in AMPK and LKB1 signaling molecules in sensory} hair cells

Our results reveal that noise exposure resulted in increased immunolabeling for total AMPK $\alpha 1$ and AMPK $\alpha 2$ in both sensory hair cells and supporting cells, with AMPK $\alpha 1$ primarily localizing in the cytosol and AMPK $\alpha 2$ localizing in both the cytosol and nuclei. Since AMPK $\alpha 2$ is localized to the nuclei, it is possible that this isoform is able to directly phosphorylate transcription factors and alter gene expression, while the $\alpha 1$ isoform may have less of an impact on gene expression and more of an effect on shortterm changes, such as the post-translational modulation of protein activity. This notion is in agreement with a report detecting expression of AMPK $\alpha 1$ mRNA in OHCs, but not in IHCs (Föller et al., 2012), suggesting that noise-induced elevation of AMPK $\alpha 1$ in IHCs may not be related to gene expression. Although noise exposure increases total AMPK $\alpha 1$ and $\mathrm{AMPK} \alpha 2$ by immunohistochemistry, the levels of total AMPK $\alpha$ protein detected by Western blots and mRNA assessed by qRT-PCR remain unchanged, possibly due to the fact that nonsensory cells in cochlear tissue may dominate the population of cells that respond to AMPK $\alpha$. On the other hand, the unchanged levels of mRNA point to a decrease in protein degradation after noise exposure.

In line with a previous report, phosphorylation of LKB1 is localized to both the nuclei and cytosol in the cells of the organ of Corti (Song et al., 2008), but p-AMPK $\alpha$ increases only in sensory hair cells after the noise exposure. This discrepancy may be owed to an effect of intrinsic differences in homeostatic defense systems 
against metabolic stress, as supporting cells are resistant to inner ear insults, while sensory hair cells are vulnerable (Tiede et al., 2009; Jensen-Smith et al., 2012; May et al., 2013). It is possible that the maintenance of homeostasis and the correction of ion imbalances in supporting cells is more effective and efficient due to the presence of gap junctions between supporting cells that allow for the diffusion and flux of ions and second messengers providing enhanced resilience compared with sensory hair cells (Denoyelle et al., 1998; Xia et al., 1998; Zhang et al., 2005; Anselmi et al., 2008; Lahne and Gale, 2010). Moreover, the antioxidant abilities of supporting cells may be stronger than those of sensory hair cells, as supporting cells secrete HSP70 (May et al., 2013), which increases the aptitude of supporting cells to recover from a metabolic disruption and prevents proapoptotic signaling pathways. In addition, LKB1 activity may play divergent roles in hair cells and supporting cells. LKB1 is known to phosphorylate a total of 14 AMPK-related kinases, including the microtubule affinity-regulating kinases, which are involved in the regulation of cellular polarity and the cytoskeleton (Lizcano et al., 2004; Jansen et al., 2009). Sensory hair cells are composed primarily of actin cytoskeleton (Han et al., 2015), making them more vulnerable than supporting cells.

\section{Conclusion}

This study proposes AMPK $\alpha$ as a novel therapeutic target to prevent NIHL. Several noise-induced events, including calcium influx, ATP depletion, and oxidative stress play a role in initiating or exacerbating the pathological responses of sensory cells. AMPK is a determining factor at a crossroads between these events and thus may constitute a more effective target to address the complexities of NIHL signaling pathways. This project evaluated losses of sensory hair cells and synaptic ribbons, as well as functional deficits in auditory brainstem response and wave I amplitudes, possibly providing an example for future evaluation of otoprotective agents.

\section{References}

Anselmi F, Hernandez VH, Crispino G, Seydel A, Ortolano S, Roper SD, Kessaris N, Richardson W, Rickheit G, Filippov MA, Monyer H, Mammano F (2008) ATP release through connexin hemichannels and gap junction transfer of second messengers propagate $\mathrm{Ca} 2+$ signals across the inner ear. Proc Natl Acad Sci U S A 105:18770-18775. CrossRef Medline

Chen FQ, Zheng HW, Hill K, Sha SH (2012) Traumatic noise activates rhofamily GTPases through transient cellular energy depletion. J Neurosci 32:12421-12430. CrossRef Medline

Chen FQ, Zheng HW, Schacht J, Sha SH (2013) Mitochondrial peroxiredoxin 3 regulates sensory cell survival in the cochlea. PLoS One 8:e61999. CrossRef Medline

Chen GD, Fechter LD (2003) The relationship between noise-induced hearing loss and hair cell loss in rats. Hear Res 177:81-90. CrossRef Medline

Denoyelle F, Lina-Granade G, Plauchu H, Bruzzone R, Chaïb H, Lévi-Acobas F, Weil D, Petit C (1998) Connexin 26 gene linked to a dominant deafness. Nature 393:319-320. CrossRef Medline

Fetoni AR, De Bartolo P, Eramo SL, Rolesi R, Paciello F, Bergamini C, Fato R, Paludetti G, Petrosini L, Troiani D (2013) Noise-induced hearing loss (NIHL) as a target of oxidative stress-mediated damage: cochlear and cortical responses after an increase in antioxidant defense. J Neurosci 33:4011-4023. CrossRef Medline

Föller M, Jaumann M, Dettling J, Saxena A, Pakladok T, Munoz C, Ruth P, Sopjani M, Seebohm G, Rüttiger L, Knipper M, Lang F (2012) AMPactivated protein kinase in BK-channel regulation and protection against hearing loss following acoustic overstimulation. FASEB J 26:4243-4253. CrossRef Medline

Han Y, Wang X, Chen J, Sha SH (2015) Noise-induced cochlear F-actin depolymerization is mediated via ROCK2/p-ERM signaling. J Neurochem 133:617-628. CrossRef Medline

Hardie DG (2003) Minireview: the AMP-activated protein kinase cascade: the key sensor of cellular energy status. Endocrinology 144:5179-5183. CrossRef Medline

Hardie DG, Salt IP, Hawley SA, Davies SP (1999) AMP-activated protein kinase: an ultrasensitive system for monitoring cellular energy charge. Biochem J 338:717-722. CrossRef Medline

Hardie DG, Scott JW, Pan DA, Hudson ER (2003) Management of cellular energy by the AMP-activated protein kinase system. FEBS Lett 546: 113-120. CrossRef Medline

Hu BH, Henderson D, Nicotera TM (2002) F-actin cleavage in apoptotic outer hair cells in chinchilla cochleas exposed to intense noise. Hear Res 172:1-9. CrossRef Medline

Jansen M, Ten Klooster JP, Offerhaus GJ, Clevers H (2009) LKB1 and AMPK family signaling: the intimate link between cell polarity and energy metabolism. Physiol Rev 89:777-798. CrossRef Medline

Jensen-Smith HC, Hallworth R, Nichols MG (2012) Gentamicin rapidly inhibits mitochondrial metabolism in high-frequency cochlear outer hair cells. PLoS One 7:e38471. CrossRef Medline

Kefas BA, Cai Y, Kerckhofs K, Ling Z, Martens G, Heimberg H, Pipeleers D, Van de Casteele M (2004) Metformin-induced stimulation of AMPactivated protein kinase in beta-cells impairs their glucose responsiveness and can lead to apoptosis. Biochem Pharmacol 68:409-416. CrossRef Medline

Kujawa SG, Liberman MC (2009) Adding insult to injury: cochlear nerve degeneration after "temporary" noise-induced hearing loss. J Neurosci 29:14077-14085. CrossRef Medline

Lahne M, Gale JE (2010) Damage-induced cell-cell communication in different cochlear cell types via two distinct ATP-dependent Ca waves. Purinergic Signal 6:189-200. CrossRef Medline

Le Prell CG, Hughes LF, Miller JM (2007) Free radical scavengers vitamins $\mathrm{A}, \mathrm{C}$, and E plus magnesium reduce noise trauma. Free Radic Biol Med 42:1454-1463. CrossRef Medline

Liberman LD, Suzuki J, Liberman MC (2015) Dynamics of cochlear synaptopathy after acoustic overexposure. J Assoc Res Otolaryngol 16:205-219. CrossRef Medline

Lizcano JM, Göransson O, Toth R, Deak M, Morrice NA, Boudeau J, Hawley SA, Udd L, Mäkelä TP, Hardie DG, Alessi DR (2004) LKB1 is a master kinase that activates 13 kinases of the AMPK subfamily, including MARK/ PAR-1. EMBO J 23:833-843. CrossRef Medline

May LA, Kramarenko II, Brandon CS, Voelkel-Johnson C, Roy S, Truong K, Francis SP, Monzack EL, Lee FS, Cunningham LL (2013) Inner ear supporting cells protect hair cells by secreting HSP70. J Clin Invest 123: 3577-3587. CrossRef Medline

McKay SE, Yan W, Nouws J, Thormann MJ, Raimundo N, Khan A, SantosSacchi J, Song L, Shadel GS (2015) Auditory pathology in a transgenic mtTFB1 mouse model of mitochondrial deafness. Am J Pathol 185: 3132-3140. CrossRef Medline

Müller M, von Hünerbein K, Hoidis S, Smolders JW (2005) A physiological place-frequency map of the cochlea in the CBA/J mouse. Hear Res 202: 63-73. CrossRef Medline

Nagashima R, Yamaguchi T, Kuramoto N, Ogita K (2011) Acoustic overstimulation activates $5^{\prime}$-AMP-activated protein kinase through a temporary decrease in ATP level in the cochlear spiral ligament prior to permanent hearing loss in mice. Neurochem Int 59:812-820. CrossRef Medline

Ohinata Y, Miller JM, Altschuler RA, Schacht J (2000) Intense noise induces formation of vasoactive lipid peroxidation products in the cochlea. Brain Res 878:163-173. CrossRef Medline

Ohlemiller KK, Wright JS, Dugan LL (1999) Early elevation of cochlear reactive oxygen species following noise exposure. Audiol Neurootol 4: 229-236. CrossRef Medline

Oishi N, Chen FQ, Zheng HW, Sha SH (2013) Intra-tympanic delivery of short interfering RNA into the adult mouse cochlea. Hear Res 296:36-41. CrossRef Medline

Schulz E, Dopheide J, Schuhmacher S, Thomas SR, Chen K, Daiber A, Wenzel P, Münzel T, Keaney JF Jr (2008) Suppression of the JNK pathway by induction of a metabolic stress response prevents vascular injury and dysfunction. Circulation 118:1347-1357. CrossRef Medline

Shen QW, Gerrard DE, Du M (2008) Compound C, an inhibitor of AMPactivated protein kinase, inhibits glycolysis in mouse longissimus dorsi postmortem. Meat Sci 78:323-330. CrossRef Medline

Song P, Xie Z, Wu Y, Xu J, Dong Y, Zou MH (2008) Protein kinase Czetadependent LKB1 serine 428 phosphorylation increases LKB1 nucleus ex- 
port and apoptosis in endothelial cells. J Biol Chem 283:12446-12455. CrossRef Medline

Suter M, Riek U, Tuerk R, Schlattner U, Wallimann T, Neumann D (2006) Dissecting the role of $5^{\prime}$-AMP for allosteric stimulation, activation, and deactivation of AMP-activated protein kinase. J Biol Chem 281:3220732216. CrossRef Medline

Tiede L, Steyger PS, Nichols MG, Hallworth R (2009) Metabolic imaging of the organ of corti-a window on cochlea bioenergetics. Brain Res 1277: 37-41. CrossRef Medline

Vicente-Torres MA, Schacht J (2006) A BAD link to mitochondrial cell death in the cochlea of mice with noise-induced hearing loss. J Neurosci Res 83:1564-1572. CrossRef Medline

Viollet B, Horman S, Leclerc J, Lantier L, Foretz M, Billaud M, Giri S, Andreelli F (2010) AMPK inhibition in health and disease. Crit Rev Biochem Mol Biol 45:276-295. CrossRef Medline

Wan G, Gomez-Casati ME, Gigliello AR, Liberman MC, Corfas G (2014) Neurotrophin-3 regulates ribbon synapse density in the cochlea and induces synapse regeneration after acoustic trauma. Elife 3:e03564. CrossRef Medline

Wang Y, Hirose K, Liberman MC (2002) Dynamics of noise-induced cellular injury and repair in the mouse cochlea. J Assoc Res Otolaryngol 3: 248-268. CrossRef Medline

Weisová P, Dávila D, Tuffy LP, Ward MW, Concannon CG, Prehn JH (2011) Role of 5'-adenosine monophosphate-activated protein kinase in cell survival and death responses in neurons. Antioxid Redox Signal 14:1863-1876. CrossRef Medline

Winder WW, Thomson DM (2007) Cellular energy sensing and signaling by AMP-activated protein kinase. Cell Biochem Biophys 47:332-347. CrossRef Medline

Xia JH, Liu CY, Tang BS, Pan Q, Huang L, Dai HP, Zhang BR, Xie W, Hu DX,
Zheng D, Shi XL, Wang DA, Xia K, Yu KP, Liao XD, Feng Y, Yang YF, Xiao JY, Xie DH, Huang JZ (1998) Mutations in the gene encoding gap junction protein beta-3 associated with autosomal dominant hearing impairment. Nat Genet 20:370-373. CrossRef Medline

Yamane H, Nakai Y, Takayama M, Iguchi H, Nakagawa T, Kojima A (1995) Appearance of free radicals in the guinea pig inner ear after noise-induced acoustic trauma. Eur Arch Otorhinolaryngol 252:504-508. CrossRef Medline

Yamasoba T, Nuttall AL, Harris C, Raphael Y, Miller JM (1998) Role of glutathione in protection against noise-induced hearing loss. Brain Res 784:82-90. CrossRef Medline

Yuan H, Wang X, Hill K, Chen J, Lemasters J, Yang SM, Sha SH (2015) Autophagy attenuates noise-induced hearing loss by reducing oxidative stress. Antioxid Redox Signal 22:1308-1324. CrossRef Medline

Yun H, Lee M, Kim SS, Ha J (2005) Glucose deprivation increases mRNA stability of vascular endothelial growth factor through activation of AMPactivated protein kinase in DU145 prostate carcinoma. J Biol Chem 280: 9963-9972. CrossRef Medline

Yun H, Kim HS, Lee S, Kang I, Kim SS, Choe W, Ha J (2009) AMP kinase signaling determines whether c-Jun $\mathrm{N}$-terminal kinase promotes survival or apoptosis during glucose deprivation. Carcinogenesis 30:529-537. CrossRef Medline

Zhang Y, Tang W, Ahmad S, Sipp JA, Chen P, Lin X (2005) Gap junctionmediated intercellular biochemical coupling in cochlear supporting cells is required for normal cochlear functions. Proc Natl Acad Sci U S A 102: 15201-15206. CrossRef Medline

Zheng HW, Chen J, Sha SH (2014) Receptor-interacting protein kinases modulate noise-induced sensory hair cell death. Cell Death Dis 5:e1262. CrossRef Medline 